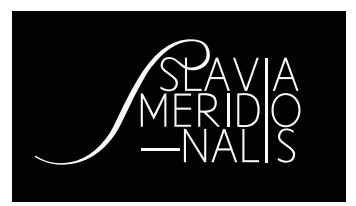

\title{
Bibliografia adnotowana naukowych prac bułgarystycznych wydanych w Polsce w latach 1947-2012
}

\author{
Sylwia Siedlecka, Instytut Slawistyki Polskiej Akademii Nauk
}

\section{Zasięg i zakres bibliografii}

Bibliografia polskiej bułgarystyki z zakresu literaturoznawstwa, kulturoznawstwa, historii oraz nauk społecznych obejmuje publikacje napisane przez autorów polskich i zagranicznych, wydane na terenie Polski w latach 1947-2012. Podstawowym językiem przywołanych w bibliografii prac jest polski, niewielka część (ok. 5\%) została napisana w języku bułgarskim.

Poniższa bibliografia jest bibliografią przedmiotową selektywną. Uwzględnia wydawnictwa zwarte - z pominięciem wydawnictw ciągłych, których umieszczenie wiązałoby się z pracą zaplanowaną na co najmniej kilka lat. Zakres bibliografii ograniczono do publikacji naukowych, które obejmują literaturoznawstwo bułgarskie, kulturoznawstwo bułgarskie, badania nad historią i społeczeństwem bułgarskim. Pominięto prace językoznawcze, które wymagałyby rozszerzenia zespołu o badaczy-językoznawców. Bibliografia jest

This is an Open Access article distributed under the terms of the Creative Commons Attribution 3.0 PL License (creativecommons.org/licenses/by/3.0/pl/), which permits redistribution, commercial and non-commercial, provided that the article is properly cited. (C) The Author(s) 2014. 
adnotowana, tj. oprócz adresu bibliograficznego i słów kluczowych zawiera streszczenia zawartości publikacji. W przypadku tomów zbiorowych - z uwagi na założenie, że jest to bardziej precyzyjna forma prezentacji zawartości publikacji - zamiast streszczeń przytacza się tytuły referatów i nazwiska autorów. Bibliografia zawiera indeks nazwisk autorów, redaktorów i tłumaczy w alfabecie łacińskim oraz w alfabecie cyrylickim. Zapisy łaciński i cyrylicki przywołane są $\mathrm{w}$ indeksie zgodnie z zapisem stosowanym w dokumencie (monografii, artykule itd.).

Podstawowe kryterium porządkowania materiału stanowi data wydania poszczególnych publikacji. Prace uszeregowane są zatem według roku wydania. Datą początkową jest rok 1947 (pierwsza powojenna praca bułgarystyczna), a końcową - rok 2012 (data ukończenia gromadzenia dokumentów). Drugie kryterium porządkowania zbioru dotyczy typów prezentowanych dokumentów, umieszczonych kolejno w obrębie każdego roku. Będą to, w kolejności:

1) słowniki i bibliografie,

2) podręczniki,

3) monografie,

4) prace zbiorowe,

5) opracowania źródłowe.

Do kategorii Słowniki i bibliografie zaliczono wydane w Polsce słowniki polsko-bułgarskie i bułgarsko-polskie. Do kategorii Podręczniki zaliczone zostały syntezy naukowe, zwłaszcza historyczne, historyczno-kulturowe oraz historycznoliterackie (np. Historia literatury bułgarskiej Teresy Dąbek-Wirgowej czy Leksykon tradycji bułgarskiej pod red. Grażyny Szwat-Gyłybowej). W Monografiach uwzględniono bułgarystyczne prace naukowe napisane przez jednego autora i poruszające wybrane zagadnienie z zakresu bułgarystyki. Do Prac zbiorowych zaliczono tomy napisane przez wielu autorów (zwłaszcza tomy pokonferencyjne), w których wątek bułgarystyczny jest główny, bądź wyraźnie zaakcentowany i zaprezentowany zwłaszcza w kontekście slawistycznym lub bałkanistycznym. $Z$ tego względu pominięto rozproszone pojedyncze artykuły w tomach zbiorowych o bardzo rozległym zakresie tematycznym. $\mathrm{W}$ adnotacjach do tomów zbiorowych przyjęto zasadę prezentacji tylko tych artykułów, które odnoszą się do tematyki bułgarystycznej bezpośrednio (prace bułgarystyczne) lub pośrednio (Bułgaria w kontekście bałkanistycznym, slawistycznym, orientalistycznym). 


\section{Grupa docelowa}

Bibliografia powstała zwłaszcza z myślą o polskich badaczach bułgarystach i stanowi ona odpowiedź na potrzebę zebrania i udostępnienia bazy bułgarystyki polskiej. Mimo dostępności sporej liczby informacji na temat prac bułgarystycznych w katalogach internetowych i w sieci duża ilość tekstów, zwłaszcza starszych, nadal pozostaje tam nieobecna, podobnie jak pojedyncze teksty bułgarystyczne znajdujące się w tomach zbiorowych, np. pokonferencyjnych, które także umieszczono w adnotacjach pod adresem bibliograficznym.

\section{Źródła}

W trakcie pracy nad bibliografią korzystałam z istniejących już bibliografii oraz opracowań. Były to przede wszystkim następujące prace: Wanda Szolginowa, Bułgaria w piśmiennictwie polskim: 1944-1963, Warszawa: Biblioteka Narodowa, 1965; Bibliografia polskich prac z zakresu slawistyki 1968-1972 pod redakcją Jadwigi Czachowskiej i Jadwigi Puzyniny, PWN 1973; Bibliografia polskich prac z zakresu slawistyki 1972-1981 pod red. Jadwigi Czachowskiej, oprac. Jacek Biesiada, PWN 1983; Piotr Głogowski, Lilla Moroz-Grzelak, Michał Stefański, Bibliografia słowianoznawstwa polskiego za lata 1996-2000. Słowiańszczyzna zachodnia i południowa, Instytut Slawistyki PAN, Instytut Filologii Słowiańskiej UW, 2002. Praca Wandy Szolginowej z 1965 roku jest jedyną polską bibliografią w całości poświęconą bułgarystyce, zawiera zarówno wydawnictwa zwarte, jak i ciągłe i była punktem odniesienia w tworzeniu poniższej bibliografii, podobnie jak Bibliografia słowianoznawstwa polskiego za lata 1996-2000. Słowiańszczyzna zachodnia i południowa, również uwzględniająca wydawnictwa zwarte i ciągłe. Korzystałam ponadto z katalogów elektronicznych, zwłaszcza katalogu zbiorów polskich bibliotek naukowych NUKAT (http://www.nukat. edu.pl) , katalogu Biblioteki Narodowej (http://alpha.bn.org.pl/) oraz katalogu Instytutu Slawistyki Polskiej Akademii Nauk (http://katalog.pan.pl/webpac-bin/231bisPL/wgbroker.exe?new+-access+top) . Ważnym źródłem, zwłaszcza w kontekście uzupełniania adnotacji treściowych, były strony internetowe ośrodków naukowych i badawczych oraz wydawnictw uniwersyteckich, na których można było odnaleźć informacje na temat zawartości części pozycji, zwłaszcza tych wydanych w ciągu ostatnich 15 lat. 


\section{Bibliografia}

\section{7}

\section{Monografie:}

1. Sławski Franciszek, Bułgaria: dzieje i piśmiennictwo w zarysie, Kraków: Wydawnictwo Studium Słowiańskiego Uniwersytetu Jagiellońskiego, 1947, ss. 42 [4].

Słowa kluczowe: historia Bułgarii; piśmiennictwo bułgarskie; literatura bułgarska; bułgarska krytyka literacka.

2. Widerszal Ludwik, Ruchy wolnościowe na Bałkanach, wyd. 2, Warszawa: Biblioteka Popularno-Naukowa. Seria Historyczna, 1947, ss. 120.

Słowa kluczowe: wyzwolenie Bułgarii; odrodzenie bułgarskie; powstanie kwietniowe; zjednoczenie Bułgarii.

Treść: Publikacja popularnonaukowa polskiego historyka, autora pracy Bułgarski ruch narodowy 1856-1872 (wyd. 1937) na temat działań i procesów wyzwoleńczych na Bałkanach od lat 50. do lat 70. XIX w.

\section{8}

\section{Prace zbiorowe:}

3. Bułgaria ludowa i przyjaźń polsko-bułgarska, Warszawa: Zarząd Główny Towarzystwa Przyjaźni Polsko-Bułgarskiej, 1948, ss. 48.

Słowa kluczowe: BRL; komunizm w Bułgarii; kultura bułgarska; literatura bułgarska. Treść: J. Sieradzki: Pakt ludów Polski i Bułgarii; S. Trojanowski: Polityka i gospodarka współczesnej Bułgarii; R. Szydłowski: Na wspólnej drodze; H. Batowski: Bułgaria w rodzinie słowiańskiej; K. Piwarski: Bułgaria w okresie II-ej wojny światowej; J. Niemiec: Spółdzielczość w rolnictwie bułgarskim; E. Zalewski: Współczesna bułgarska wieś spółdzielcza; M. Weralski, Spólnota rolna w Slatinie; D. Gabe: Droga dzisiejszej literatury bułgarskiej; K. M. Kuev: Powstanie wrześniowe 1923 r. w literaturze butgarskiej; B. Czantor: Bułgarski poeta proletariatu; A. Brosz: Trzy jubileusze literackie; L. Rubach: Teatr i kino bułgarskie po 9 września; I. Petrov: Towarzystwo Bułgarsko-Polskie; L. Rubach: Towarzystwo Przyjaźni Polsko-Bułgarskiej. 


\section{1}

\section{Prace zbiorowe:}

4. Iwan Wazow. 1850-1921, red. Henryk Batowski, Warszawa: Komitet Słowiański w Polsce, 1951, ss. 48.

Słowa kluczowe: Iwan Wazow; literatura bułgarska; Wyzwolenie Bułgarii; proza bułgarska; poezja bułgarska.

Treść: S. Pollak: Iwan Wazow - poeta wyzwolenia narodowego Bułgarii; L. Stojanow: Wazow - wielki poeta narodowy; Todor Pavlov: Pierwiastki społeczne twórczości Wazowa; Kujo M. Kuev: Przyczynki do estetyki Wazowa; Z twórczości Iwana Wazowa (wiersze i proza); Brosz Antoni: Wazow w Polsce (materiały bibliograficzne).

\section{3}

\section{Monografie:}

5. Dankowicz Henryk, 9 lat demokratycznej Bułgarii, Warszawa: Towarzystwo Wiedzy Powszechnej, 1953, ss. 32.

Słowa kluczowe: BRL; 9 września 1944; komunizm w Bułgarii; historia Bułgarii, społeczeństwo bułgarskie.

6. Dankowicz Henryk, Ludowa Bułgaria, Warszawa: „Wiedza Powszechna”, 1953, ss. 70 [2].

Słowa kluczowe: BRL; komunizm w Bułgarii, historia Bułgarii; polityka bułgarska. Treść: Broszura prezentująca polskiemu odbiorcy najważniejsze informacje na temat bułgarskiej historii i życia społeczno-politycznego po 1944 roku.

\section{6}

\section{Monografie:}

7. Dankowicz Henryk, Nowa Bułgaria, Warszawa: „Wiedza Powszechna”, 1956, ss. 60 [3].

Słowa kluczowe: BRL; komunizm w Bułgarii; społeczeństwo bułgarskie; historia Bułgarii; 9 września $1944 \mathrm{r}$.

Treść: Broszura zawierająca ogólny zarys wiedzy na temat bułgarskiej historii i życia społeczno-politycznego po roku 1944, akcentująca element „nowego początku” w dziejach Bułgarii, czyli daty 9 września 1944 roku, tj. wprowadzenie rządu komunistów. 


\section{1}

\section{Słowniki i bibliografie:}

8. Radewa Sabina, Słownik polsko-bułgarski = Българско-полски речник, Warszawa: „Wiedza Powszechna”, 1961, ss. 911 [3].

Słowa kluczowe: słowniki polsko-bułgarskie; język bułgarski; język polski; słownictwo; przekład.

\section{3}

\section{Słowniki i bibliografie:}

9. Sławski Franciszek, Podręczny słownik bułgarsko-polski $=$ Наръчен българско-полски речник, Warszawa: „Wiedza Powszechna”, 1963, ss. 1258 [2].

Słowa kluczowe: słowniki bułgarsko-polskie; język bułgarski; język polski; słownictwo; przekład.

\section{Monografie:}

10. Bartelski Lesław Marian, Jeździec z Madary: szkice o ziemi bułgarskiej, Warszawa: „Książka i Wiedza”, 1963, ss. 452 [2].

Słowa kluczowe: Jeździec z Madary; Trakowie; panowanie tureckie; komunizm w Bułgarii; bułgarskie średniowiecze; archeologia bułgarska; kultura bułgarska.

Treść: Zbiór szkiców (2 wydanie 1966, 3 - 1977) poświęconych najważniejszym wydarzeniom w historii politycznej i kulturalnej Bułgarii. Autor nie rości sobie pretensji do naukowości, książka ma charakter literacki, ale opiera się na materiałach źródłowych. Poszczególne części sięgają w przeszłość, także do czasów trackich, do okresu powojennego. Książka składa się z czterech części: Jeździec z Madary, Trakowie, Narodziny i upadek państwa, Pod jarzmem (pięć wieków panowania tureckiego do końca drugiej wojny światowe) oraz Dzban $z$ Neseber (okres po 9 września 1944 roku).

\section{4}

\section{Monografie:}

11. Możejko Edward, Sztuka pisarska Jordana Jowkowa, Wrocław: Zakład Narodowy im. Ossolińskich, 1964, ss. 210 [2]. 
Słowa kluczowe: Jordan Jowkow; proza bułgarska; opowiadanie bułgarskie; impresjonizm; symbolizm.

Treść: Monografia dotyczy artystycznych aspektów prozy wybitnego prozaika bułgarskiego Jordana Jowkowa (1880-1937). Autor śledzi ewolucję artystycznych form w dziełach prozaika, włączając w obręb badań również najwcześniejsze, często pomijane przez badaczy, utwory. Osią zainteresowania autora monografii są problem narratora i stylu, impresjonizm i symbolika wczesnej prozy Jowkowa oraz ludowość opowiadań prozaika w twórczości po roku 1920.

12. Rubach Ludomir, 20 lat Ludowej Republiki Bułgarii, Warszawa: „Ludowa Spółdzielnia Wydawnicza”, 1964, ss. 103 [5].

Słowa kluczowe: BRL; 9 września 1944 r.; komunizm w Bułgarii; historia Bułgarii; społeczeństwo bułgarskie.

Treść: Publikacja rocznicowa z okazji 20-lecia istnienia Bułgarskiej Republiki Ludowej, omawiająca w propagandowej retoryce osiągnięcia pierwszego dwudziestolecia komunistycznej Bułgarii.

\section{5}

\section{Bibliografie:}

13. Szolginowa Wanda, Bułgaria w piśmiennictwie polskim: 1944-1963, Warszawa: Biblioteka Narodowa, 1965, ss. 216 [1].

Słowa kluczowe: bułgarystyka; Bułgaria; polskie bibliografie; język bułgarski; literatura bułgarska.

\section{7}

\section{Monografie:}

14. Możejko Edward, Iwan Wazow, Warszawa: „Wiedza Powszechna”, 1967, ss. 201 [3].

Słowa kluczowe: Iwan Wazow; literatura bułgarska; biografie bułgarskie.

Treść: Biografia Iwana Wazowa wydana w znanej w okresie PRL-u kieszonkowej serii „Profile”, popularyzującej dorobek autorów polskich i światowych. 


\section{8}

\section{Monografie:}

15. Czajka Henryka, Bułgarska i macedońska historyczna pieśń ludowa, red. nauk. Józef Magnuszewski, Wrocław: Zakład Narodowy im. Ossolińskich, 1968, ss. 164.

Słowa kluczowe: kultura ludowa bułgarska; kultura ludowa macedońska; bułgarska pieśń ludowa; macedońska pieśń ludowa; krytyka literacka; etnografia bułgarska.

Treść: Przedmiotem rozważań jest ludowa pieśń historyczna Bułgarów i Macedończyków. Na materiał bułgarski i macedoński spojrzano jako na całość, wspólne poetyckie dziedzictwo obu narodów. W pierwszej części autorka analizuje pieśni junackie. Druga część jest poświęcona pieśniom historycznym (pieśni o niewoli tureckiej; pieśni o wolności, np. hajduckie, o rewolucjonistach, o powstaniu kwietniowym, o wojnie rosyjsko-tureckiej; pieśni wyzwoleńcze powstałe u progu XX wieku, np. o wojnie serbsko-bułgarskiej, o powstaniu ilindenskim). W ostatniej części analizie poddano artystyczny aspekt pieśni ludowej.

\section{9}

\section{Monografie:}

16. Dąbek-Wirgowa Teresa, Twórczość przekładowa Dory Gabe, Wrocław: Zakład Narodowy im. Ossolińskich - Wydawnictwo PAN, 1969, ss. 176 [1]. Słowa kluczowe: Dora Gabe; literatura bułgarska; literatura polska; przekłady bułgarskie; Jan Kasprowicz; Juliusz Słowacki.

Treść: Praca poświęcona działalności translatorskiej bułgarskiej poetki, pisarki i tłumaczki Dory Gabe. Oprócz szczegółowego omówienia początków twórczości przekładowej Dory Gabe, projektu antologii poezji polskiej jej autorstwa, przekładów polskiego dramatu i prozy, jak również analizy roli Gabe jako tłumaczki i popularyzatorki poezji Kasprowicza oraz jej prac nad przekładem „Anhellego” Słowackiego, autorka omawia rolę literatury polskiej w oryginalnej i przekładowej twórczości Dory Gabe w latach 1925, jej udział w najnowszych dziejach bułgarsko-polskich związków literackich, sytuując swoje rozważania na tle głównych problemów bułgarsko-polskich stosunków literackich w pierwszych dekadach XX wieku. 


\section{0}

\section{Podręczniki:}

17. Wasilewski Tadeusz, Historia Bułgarii, Wrocław: Zakład Narodowy im. Ossolińskich, 1970.

Słowa kluczowe: historia Bułgarii; polityka Bułgarii; kultura Bułgarii; podręczniki o Bułgarii.

Treść: Zarys historii Bułgarii od dziejów Tracji do powstania Bułgarskiej Republiki Ludowej, przedstawiony częściowo w sposób tendencyjny (np. trackie korzenie Bułgarów). Drugie, uzupełnione i poprawione wydanie pochodzi z 1988 roku.

\section{Prace zbiorowe:}

18. Braterstwo, przyjaźń. Szkice z dziejów przyjaźni polsko-bułgarskiej, wybór i opracowanie Jan Świerczyński, Warszawa: Wydawnictwo MON, 1970.

Słowa kluczowe: BRL; PRL; literatura bułgarska; literatura polska; polityka międzynarodowa; stosunki polsko-bułgarskie.

Treść: J. Cyrankiewicz: Dwa zaprzyjaźnione narody; T. Żiwkow, Przyjaźń między dwoma słowiańskimi narodami; W. Jaruzelski: Przyjaźń i braterstwo między dwoma narodami; D. Dżurow: Polsko-bułgarskie braterstwo broni; A. Semerdżijew: Na straży wolności i socjalizmu; I. Jakubowski: Niewzruszone braterstwo broni; K. Majewski: Archeologowie polscy $w$ Bułgarii; T. Wasilewski: Polska $w$ walce $z$ ekspansja turecka w Europie - uchodźcy bułgarscy w Polsce; D. Dymitrow: Piotr Parczewicz w Polsce; D. Kosew: Polscy i bułgarscy rewolucjoniści w walce narodowowyzwoleńczej w XIX w.; E. Nikołow: W Burgas; M. Stojanow: Polska w piśmiennictwie bułgarskiego Odrodzenia; D. Dojnow: Polscy przyjaciele Christa Botewa; S. Petrow: Polacy w walkach o wyzwolenie Bułgarii (1877-1878); A. Koseski: Społeczeństwo polskie wobec wyzwolenia Butgarii w latach 1877-1878; S. Lorentz: O kontaktach artystycznych polsko-bułgarskich; C. Dimitrow: Zjednoczenie Bułgarii w 1885 r. a społeczeństwo polskie; P. Dinekow: Postać Bułgarii w powieści Zygmunta Miłkowskiego „W zaraniu”; J. Magnuszewski: Penczo Sławejkow a Mickiewicz; G. Iwanow: Wczesne kontakty rewolucyjne i socjalistyczne; A. Tymieniecka: Komunistyczna Partia Polski wobec bułgarskiego ruchu rewolucyjnego; G. Miszkow: Solidarność narodów bułgarskiego i polskiego w latach światowego kryzysu ekonomicznego 1929-1933; M. Malinowski: Dymitrow a polski ruch robotniczy; F. Księżarczyk: W obronie Hiszpanii; F. Kozowski: O moich kontaktach z polskimi uczestnikami brygad międzynarodowych; G. Miszkow: Bojownik o przyjaźń bułgarsko-polska; E. Stachurski: Antyfaszystowska walka Polaków i Bułgarów podczas drugiej wojny światowej; W. Iwanow: „Oda do młodości” i partyzanci bułgarscy; J. Śliziński: Christo Botew w Polsce; H. Czajka: Literatura bułgarska w Polsce do 1918 r.; T. Dąbek: 
Proza bułgarska oczyma czytelników polskich; A. Kamieńska: Trwały pomost (Poezja bułgarska w Polsce); D. Ikonomow: Literatura polska w Bułgarii; A. Olcha: W nurcie polsko-bułgarskiej wymiany kulturalnej; J. Toszkow: Braterskie kontakty kulturalne; J. Świerczyński: Współpraca; P. Todorow: Turystyka przejawem przyjaźni; S. Stoew: Przyjaźn sportowa; Z. Czerwiński: Przyjaciele; R. Złatkow: Ogniwa przyjaźni; Gwiazdy nie wzeszły; M. Konopnicka: Petko Sławejkow; W. Mach: Góry nad Czarnym Morzem; L. M. Bartelski: Jeździec z Madary.

\section{1}

\section{Prace zbiorowe:}

19. Stosunki literackie polsko-bułgarskie. Studia, red. Jerzy Śliziński, Wrocław: Zakład Narodowy im. Ossolińskich, 1971, ss. 204 [1].

Słowa kluczowe: literatura bułgarska; literatura polska; kultura bułgarska; bułgarskie stosunki literackie.

Treść: В. Паскалева: Дневникът на Людовик Пшесмицки от престоя му в България; П. Динеков: Христо Ботев і Полиа; В. Jaroszewicz-Kleindienst: Recepcja twórczości Christo Botewa w Polsce; Е. Георгиев: Българската тема в полската литература и полското обществено и литературно развитие; R. Pęgierska-Piotrowska: Problematyka bułgarska w pracach Bronisława Grabowskiego; J. Reychman: Zasługi Jana Grzegorzewskiego na polu zblizenia kulturalnego bułgarsko-polskiego; K. Wierzbicka: Recepcja twórczości Penczo Sławejkowa w Polsce; J. Śliziński: Recepcja twórczości Iwana Minczewa Wazowa w Polsce; К. М. Куев: Сенкевичевият роман „Кргстоносци” на български език; J. Kamiński: Jordan Jowkow w Polsce; J. Russocka: Elin Pelin w Polsce; S. Bylina: Syntetyczne opracowania dziejów literatury bułgarskiej w Polsce międzywojennej; W. Medyńska: O recepcji i przekładach Elizawety Bagriany w Polsce; E. Madany: Literatura bułgarska w Polsce po II wojnie światowej. Zawiera również Materiały do bułgarskiej bibliografii literackiej w Polsce, opracowane przez zespół pod kierunkiem J. Ślizińskiego (s. 179-194).

\section{3}

\section{Słowniki i bibliografie:}

20. Bibliografia polskich prac z zakresu slawistyki (1968-1972), red. Jadwiga Czachowska, Warszawa: PWN, 1983.

Słowa kluczowe: bibliografie; slawistyka; słowianoznawstwo. 


\section{Monografie:}

21. Czajka Henryka, Bohaterska epika ludowa Słowian południowych: struktura treści, Wrocław: Zakład Narodowy im. Ossolińskich - Wydawnictwo PAN, 1973, ss. 219 [1].

Słowa kluczowe: Słowianie południowi; literatury słowiańskie; słowiańska poezja ludowa; kultura słowiańska.

Treść: Próba analizy epiki bohaterskiej Słowian południowych z różnych perspektyw: historycznej, mitycznej, chrześcijańskiej, baśniowej i obyczajowej. Autorka wyodrębnia poszczególne warstwy w epice ludowej, traktuje je jako oddzielne komponenty pieśni, za główne komponenty epiki bohaterskiej południowej Słowiańszczyzny uznając mit pogański i obyczajowość.

22. Dąbek-Wirgowa Teresa, Penczo Sławejkow: tradycjonalizm i nowatorstwo, Wrocław: Zakład Narodowy im. Ossolińskich, 1973, ss. 174 [1].

Słowa kluczowe: Penczo Sławejkow; poezja bułgarska; krąg „Myśl”; modernizm bułgarski; europeizacja; kultura bułgarska.

Treść: Monografia poświęcona jednej z kluczowych postaci bułgarskiego modernizmu. W kolejnych rozdziałach autorka analizuje między innymi nieporozumienia wokół postaci Sławejkowa i jego dziedzictwa w bułgarskiej kulturze, zagadnienia związane z narodzinami oraz ideowym zapleczem kręgu „Myśl”, główne tematy, motywy i style twórczości Sławejkowa, jak również mistyfikacje i maski, które przyjmował w ramach dialogu z kulturą rodzimą i europejską.

\section{6}

\section{Monografie:}

23. Naumow Aleksander, Biblia w strukturze artystycznej utworów cerkiewnosłowiańskich, Wrocław: Zakład Narodowy im. Ossolińskich, 1976, ss. 165.

Słowa kluczowe: Biblia; apokryfy; literatura staro-cerkiewno-słowiańska; prawosławie; Słowiańszczyzna.

Treść: Rozdział I: O specyfice komunikacji literackiej w prawosławnym średniowieczu; Rozdział II: Miejsce Biblii w strukturze prawosławnej Słowiańszczyzny; Rozdział III: Elementy biblijne w strukturze utworów cerkiewnostowiańskich. A: Stużby. B: Modlitwy. C: Mowy. D: Komponowanie obrazu postaci: mowy i żywoty; E: Podsumowanie.

24. Skowronek Jerzy, Polityka bałkańska Hotelu Lambert: 1833-1856, Warszawa: Uniwersytet Warszawski, 1976, ss. 227 [1]. 
Słowa kluczowe: Adam Czartoryski; Hotel Lambert; Wiosna Ludów; Bałkany; Polacy na Bałkanach.

Treść: Praca przedstawia w układzie chronologicznym główne zagadnienia związane z polityką Hotelu Lambert na Bałkanach. Autor pisze o pierwszych akcjach i organizacji Agencji Głównej (1841-1843), okresie najszerszych akcji bałkańskich (1843-1845), próby tworzenia bazy dla działań w Polsce (1845-1847) oraz okresie Wiosny Ludów, załamania się szerokich akcji bałkańskich (1848-1856), a także analizuje sprawy bałkańskie jako element ideologii Hotelu Lambert.

\section{7}

\section{Podręczniki:}

25. Historia Słowian południowych i zachodnich, Skowronek Jerzy, Tanty Mieczysław, Wasilewski Tadeusz, Warszawa: Państwowe Wydawnictwo Naukowe, 1977, ss. 770 [2].

Słowa kluczowe: Słowianie Południowi; Słowianie Zachodni; historia Słowian; kultura Słowian; sztuka Słowian.

Treść: Pierwsze wydanie syntetycznej pracy z zakresu historii Słowian Południowych i Zachodnich, która od lat siedemdziesiątych (kolejne wydania, zmienione i poprawione, w latach 1988, 2005) stanowi jeden $\mathrm{z}$ najważniejszych podręczników w polskich akademickich placówkach slawistycznych (slawistyka zachodnia i południowa). Ramy czasowe wyznacza moment pojawienia się Słowian południowych i zachodnich na arenie dziejowej (VI w.), a kończy XX wiek. Oprócz tematyki historycznej podręcznik zawiera podrozdziały poświęcone kulturze i sztuce Słowian.

\section{Monografie:}

26. Żmigrodzki Marek, System partyjny Ludowej Republiki Bułgarii, Warszawa: PWN, 1977, ss. 246 [2].

Słowa kluczowe: BRL; bułgarskie partie polityczne; komunizm w Bułgarii; Bułgarska Partia Komunistyczna; Bułgarski Ludowy Związek Chłopski.

Treść: Autor klasyfikuje systemy partyjne w Bułgarii oraz opisuje kształtowanie się systemu partyjnego w Bułgarii po 9 września 1944 roku i jego poszczególne fazy. Skupia się na kwestii kierowniczej roli Bułgarskiej Partii Komunistycznej w stosunku do państwa. Dwa z rozdziałów są także poświęcone roli Bułgarskiego Ludowego Związku Chłopskiego jako partii sojuszniczej w systemie partyjnym Ludowej Bułgarii oraz zakresowi i formom współpracy BPK i BLZCh. 


\section{8}

\section{Słowniki i bibliografie:}

27. Korytkowska Małgorzata, Raczewa-Stratijewa Lilija, Słownik minimum bułgarsko-polski, polsko-bułgarski, Warszawa: „Wiedza Powszechna”, 1978, ss. 501 [3].

Słowa kluczowe: słowniki polsko-bułgarskie; słowniki bułgarsko-polskie; język bułgarski; język polski; przekład.

\section{Prace zbiorowe:}

28. Ludowa Republika Bułgarii, red. nauk. Adam Koseski, Warszawa: Krajowa Agencja Wydawnicza, 1978, ss. 231 [1].

Słowa kluczowe: BRL, komunizm w Bułgarii; informatory o Bułgarii; społeczeństwo bułgarskie; polityka bułgarska.

Treść: Publikacja wydana w popularnej serii Krajowej Agencji Wydawniczej „U Przyjaciół”, mająca propagować w Polsce upolitycznioną narrację na temat sąsiednich krajów socjalistycznych.

\section{9}

\section{Monografie:}

29. Zawilski Apoloniusz, O wolność Bułgarii, Warszawa: Wydawnictwa MON, 1979, ss. 378 [2].

Słowa kluczowe: historia Bułgarii; powstania bułgarskie; wojna krymska; wojna rosyjsko-turecka; bułgarskie odrodzenie narodowe; Hotel Lambert.

Treść: Publikacja, autorstwa pułkownika Wojska Polskiego, skazanego na karę śmierci w latach pięćdziesiątych XX wieku (spędził w celi śmierci 2 lata, wyrok unieważniono w roku 1956) Praca prezentuje najważniejsze wydarzenia $\mathrm{z}$ historii politycznej (w mniejszym stopniu kulturowej) Bułgarów od odrodzenia narodowego do pierwszej wojny światowej. Wywód porządkowany jest przez chronologicznie przedstawione wydarzenia $\mathrm{z}$ historii Bułgarii (przez pierwsze spontaniczne powstania w północno-zachodniej Bułgarii, walki o niezależność kościoła bułgarskiego, powstanie starozagorskie, kwietniowe, do bitwy o Szipkę, pod Plewną i nad Czarnym Łomem, wojen bałkańskich i pierwszej wojny światowej) oraz prezentację działalności kluczowych postaci bułgarskiego ruchu narodowego (Lewski, Rakowski, Karawełow). Emancypacyjne dążenia Bułgarów przedstawiono w kontekście międzynarodowych 
relacji politycznych w XIX wieku: relacji bułgarsko-tureckich, bułgarsko-polskich (Hotel Lambert, wojna krymska) i bułgarsko-rosyjskich (sukcesy wojsk rosyjskich i ochotników bułgarskich podczas wojny rosyjsko-tureckiej 1877-1878).

30. Znamierowska-Rakk, Elżbieta, Rozwój stosunków Bułgarii z Grecja i Turcja po II wojnie światowej 1944-1975, Wrocław: Zakład Narodowy im. Ossolińskich, 1979, ss. 236.

Słowa kluczowe: BRL; II wojna światowa; stosunki grecko-bułgarskie; stosunki turecko-bułgarskie.

Treść: Autorka omawia na wstępie historyczne uwarunkowania stosunków Bułgarii z Grecją i Turcją z uwzględnieniem sytuacji międzynarodowej zarówno na Bałkanach, jak i w Europie, począwszy od końca XIX wieku. Zasadniczą część pracy stanowi analiza, przedstawiona w układzie przedmiotowo-chronologicznym, dotycząca wydarzeń i procesów z zakresu stosunków Sofii z Ankarą i Atenami. Analizę ujęto w dwa nurty: jeden - poświęcony stosunkom Bułgarii z Grecją, drugi - dotyczący stosunków Bułgarii z Turcją. Podstawowe materiały źródłowe stanowią dokumenty archiwalne (głównie z Centralnego Państwowego Archiwum BRL) oraz prasowe (głównie prasa bułgarska, grecka i turecka).

\section{0}

\section{Podręczniki:}

31. Dąbek-Wirgowa Teresa, Historia literatury bułgarskiej. Zarys, Warszawa - Wrocław: Zakład Narodowy im. Ossolińskich, 1980, ss. 318 [1].

Słowa kluczowe: literatura bułgarska; piśmiennictwo starobułgarskie; bułgarska proza; bułgarska poezja, bułgarski dramat; odrodzenie narodowe; Wyzwolenie Bułgarii.

Treść: Pierwsza polska syntetyczna prezentacja historii literatury bułgarskiej od średniowiecza (piśmiennictwo starobułgarskie) do drugiej połowy XX wieku. Kolejne części dotyczą okresów historycznych (piśmiennictwo starobułgarskie, odrodzenie narodowe, literatura od wyzwolenia do I wojny światowej, okres międzywojenny, literatura po roku 1944). Materiał w każdej części podlega rozróżnieniom ze względu na rodzaj literacki (poezja, proza, dramat). Publikacja zawiera bibliografię przekładów literatury bułgarskiej na język polski.

\section{Monografie:}

32. Koseski Adam, Ludowa Republika Bułgarii: zarys rozwoju społeczno-politycznego, Warszawa: Wydawnictwa MON, 1980, ss. 287 [1]. 
Słowa kluczowe: BRL; polityka bułgarska; obronność w Bułgarii; komunizm w Bułgarii; Todor Żiwkow; realny socjalizm.

Treść: Praca wydana w serii „Ideologia. Polityka. Obronność” MON-u rozpoczyna się apologetycznym cytatem z przemówienia Todora Żiwkowa. Studium obejmuje okres od lat powojennych (utworzenie Frontu Ojczyźnianego) do końca lat osiemdziesiątych XX wieku. Autor skupia się na historii Bułgarii wyznaczanej przez kolejne Zjazdy Bułgarskiej Partii Komunistycznej, widząc w Bułgarii okresu realnego socjalizmu lat siedemdziesiątych XX wieku dojrzałą i słuszną realizację kilkuetapowej drogi do celu.

\section{Tomaszewski, Jerzy, Rozwój Bułgarii w latach 1944-1956, Warszawa:} Wydawnictwa Uniwersytetu Warszawskiego, 1980, ss. 189.

Słowa kluczowe: BRL; stalinizm w Bułgarii; „odwilž”; bułgarskie stosunki międzynarodowe; gospodarka Bułgarii.

Treść: Analizowany materiał obejmuje zagadnienia z zakresu przemian politycznych, społecznych i gospodarczych Bułgarii w latach 1944-1956. Autor, wychodząc od wydarzeń związanych $\mathrm{z}$ walką o władzę $\mathrm{w}$ Bułgarii, klęsk prawicy w połowie lat czterdziestych, przez zagadnienia polityki zagranicznej w latach 1944-1947, przemiany polityki i zmiany w układzie sił w latach 1948-1949, kończy wywód analizą głównych kierunków rozwoju Bułgarii w latach 1950-1956, skupiając się zwłaszcza na zmianach politycznych, uprzemysłowienia, rolnictwa, statusu życia społeczeństwa, polityki zagranicznej, sygnalizując również „pierwsze objawy odnowy” związane ze zmianami w układzie sił w bloku komunistycznym.

\section{1}

\section{Monografie:}

34. Jackowicz Jerzy, Traktat pokojowy z Bułgaria 1947, Wrocław: Zakład Narodowy im. Ossolińskich, 1981, ss. 308.

Słowa kluczowe: traktat z Bułgarią 1947; bułgarska polityka międzynarodowa; konferencja paryska 1946; komunizm w Bułgarii.

Treść: Próba całościowego opracowania skomplikowanej problematyki traktatu pokojowego z Bułgarią, który miał istotne znaczenie dla ukształtowania się powojennej bułgarskiej rzeczywistości politycznej. Zasadnicza część pracy mieści się w ramach czasowych 1944-1947. Wykorzystano dokumenty archiwalne, stenogramy konferencji paryskiej z roku 1946, stenogramy posiedzeń parlamentu bułgarskiego, prasę, opracowania i pamiętniki. Walka o warunki traktatu została przedstawiona na tle sytuacji międzynarodowej i wewnętrznej Bułgarii. 


\section{Prace zbiorowe:}

35. Od Wisty do Maricy: 681-1981 = От Висла до Мариц, Kraków: Towarzystwo Przyjaźni Polsko-Bułgarskiej, 1981, ss. 310 [2].

Słowa kluczowe: bułgarystyka w Polsce; polonistyka w Bułgarii; literatura bułgarska; język bułgarski.

Treść: Zawiera m.in. teksty referatów wygłoszonych na sesji naukowej (11-13 X 1979) zorganizowanej przez Uniwersytet Jagielloński z okazji 80-lecia bułgarystyki polskiej. Spis referatów: Część I. 13 wieków. F. Sławski: Na 1300-lecie państwa bułgarskiego; T. Cieślak: Przez trzynaście wieków. Refleksje o dziejach Bułgarii; L. M. Bartelski: Jeździec z Madary; K. Majewski: Bułgarsko-polskie badania archeologiczne miasta rzymskiego Novae w Bułgarii; J. Magnuszewski: Jak nas widzieli; S. Maciejewski: Dwie gwiazdy; F. Sławski: Najstarsze pismo słowiańskie. Część II. Historia bułgarystyki polskiej i polonistyki bułgarskiej. J. Rusek: Bułgarystyka w Uniwersytecie Jagiellońskim; T. Dąbek-Wirgowa: Polska bułgarystyka historycznoliteracka; H. Czajka: Zainteresowanie folklorem bułgarskim $w$ Polsce; K. M. Kuew: Lektorat języka bułgarskiego w Krakowie w latach 1937-1939; S. Radewa: Parę słów o pierwszych krokach powojennej bułgarystyki polskiej; M. Karpaczewa: Wspomnienia lektora; W. Kot: Tadeusz Stanisław Grabowski - bułgarysta; С. Иванчев: Полската филология в България; W. Popowa: Język polski w Bułgarii; B. Biołczew: Lata moich studiów w Krakowie; Т. Бояджиев: Мечислав Малецки в българска диалектология; Р. Русинов: Иван Леков и полското езикознание; Л. Селимски: Стефан Младенов и полското езикознание; E. Georgiew: Polacy i formowanie się demokratycznej i rewolucyjnej ideologii i poetyki u bułgarskich pisarzy Odrodzenia Narodowego; Б. А. Цветкова: Походите на Владислав III Ягело и Янош Хуняди през 1443-1444 г. Европейски югоизток и българите; C. Genow: Wspomnienia Polaka Ludwika Przesmyckiego o Bułgarii 1829 r.; Część III. Debiuty. G. Szwat-Gyłybow: Narrator w prozie Radiczkowa z lat sześćdziesiątych; M. Grochowina: „Przygody Goromołowa” Jordana Jowkowa jako aluzja literacka do „Don Kichota” M. Cervantesa.

36. Polska i Bułgaria w okresie budownictwa socjalizmu, red. Wiesław Balcerak, Warszawa: PWN, 1981, ss. 352.

Słowa kluczowe: BRL; PRL; socjalizm w Bułgarii; partie bułgarskie; stosunki polsko-bułgarskie; BKP; PZPR.

Treść: A. Czubiński: Historyczne przesłanki utworzenia Polskiej Rzeczypospolitej Ludowej; M. Isusow: Utworzenie politycznego systemu edukacji ludowej w Bułgarii (1944-1948) i jego rozwój; T. Walichnowski: Likwidacja zbrojnego podziemia w okresie utrwalania władzy ludowej w Polsce; N. Kołomiejczyk: Niektóre problemy strategii budowy podstaw socjalizmu PZPR i BPK; Z. Hemmerling: Partie chłopskie w okresie 
kształtowania się władzy ludowej 1944-1949; B. Mateew: Polityka rolna władzy ludowo-demokratycznej w Bułgarii w latach 1944-1948; Z. Klejn: Z problematyki kolektywizacji wsi w Bułgarii; W. Cziczowska: Inteligencja twórcza w rewolucji ludowo-demokratycznej w Bułgarii (1944-1948); Z. Zlatew: Studia o systemie demokracji ludowej w Bułgarii; J. Jackowicz: Stosunki polsko-bułgarskie w latach 1945-1948; A. Koseski: Koncepcja budowy rozwiniętego społeczeństwa socjalistycznego w programach PZPR i BPK. Próba analizy porównawczej.

\section{2}

\section{Opracowania źródłowe:}

37. Dokumenty i materiały do historii stosunków polsko-bułgarskich. T. 1 (1918-1944), oprac. Wiesław Balcerak, Todor Dobrijanow, red. Wiesław Balcerak, Angeł Nakow, red. nauk. W. Balcerak, Wrocław: Zakład Narodowy im. Ossolińskich, 1982, ss. 746 [1].

Słowa kluczowe: historia Bułgarii; druga wojna światowa; stosunki polsko-bułgarskie.

\section{3}

\section{Słowniki i bibliografie:}

38. Bibliografia polskich prac z zakresu slawistyki (1972-1981), red. Jadwiga Czachowska, oprac. J. Biesiada, Warszawa: PWN, 1983.

Słowa kluczowe: bibliografie; slawistyka; słowianoznawstwo.

\section{Monografie:}

39. Gałązka Wojciech, Tradycja i współczesność. O literaturze bułgarskiej XX wieku, Katowice: „Śląsk”, 1983, ss. 315 [1].

Słowa kluczowe: poezja bułgarska; witalizm bułgarski; ekspresjonizm bułgarski; bułgarskie manifesty literackie; symbolizm bułgarski; Elin Pelin; Jordan Radiczkow; Atanas Dałczew.

Treść: Książka zawiera zbiór tekstów historycznoliterackich pogrupowanych w dwie części. Głównym tematem części pierwszej są kierunki rozwojowe poezji bułgarskiej w międzywojniu (witalizm, ekspresjonizm, sztuka rodzima, poezja proletariacka i poezja realizmu socjalistycznego, prymitywizm). W drugiej części, zawierającej syntezy i interpretacje, autor porusza problemy: periodyzacji literatury nowobułgarskiej, obcości i rodzimości w ekspresjonizmie bułgarskim, programów i manifestów 
literackich, zagadnień związanych z symbolizmem bułgarskim. Znajdują się tu także interpretacje twórczości Nikołaja Liliewa, Elina Pelina, Jordana Radiczkowa i dorobku Atanasa Dałczewa.

40. Skowronek, Jerzy, Sprzymierzeńcy narodów bałkańskich, Warszawa: PWN, 1983, 427 [1] s.

Słowa kluczowe: historia Bułgarii; Bałkany XIX w.; kryzys egipski; bałkańskie ruchy narodowe; Wiosna Ludów.

Treść: Praca dotyczy intensywnych kontaktów polsko-bałkańskich w okresie 1795-1849, tj. czasie rozwoju ruchów narodowych oraz dążeń wolnościowych narodów bałkańskich i polskiego. Autor analizuje między innymi kwestie związane z inicjatywami polskimi na Bałkanach w latach 1825-1831, w dobie kryzysu egipskiego (1831-1840), wielkie projekty i inicjatywy polityczne Polaków w latach $1841-1847$, jak również okres nadziei i rozczarowań w latach 1848-1849.

\section{Prace zbiorowe:}

41. 1300-lecie państwa bułgarskiego: 681-1981. Materiały z sesji naukowej, red. Tadeusz Zdancewicz, Poznań: UAM, 1983, ss. 111 [1].

Słowa kluczowe: powstanie państwa bułgarskiego; BRL; kraje bałkańskie; ruchy wyzwoleńcze na Bałkanach; literatura bułgarska; język bułgarski.

Treść: П. Ангелов: Тысяча трехсотлетие болгарской културы и просвещения; S. Parnicki-Pudełko: Polskie badania nad kulturą rzymską w Bułgarii. Skrót referatu; Т. Шишкова: Георги Димитров - виден дееи и теоретик на българското и международното работническо движение; B. Koszel: Rola Bułgarii na Bałkanach w okresie międzywojennym; S. Sierpowski: Międzynarodowe znaczenie konfliktu grecko-bułgarskiego w 1925 r.; W. Swoboda: Powstanie państwa bułgarskiego na tle słowiańskich procesów państwowotwórczych na Bałkanach; B. Krupski: Związki literackie polsko-bułgarskie do roku 1925; H. Pańczyk: Literatura bułgarska w kontekście europejskim.

42. Trzynaście wieków Bułgarii. Materiały polsko-bułgarskiej sesji naukowej, Warszawa 28-30 X 1981, red. Janusz Siatkowski; Wrocław: Zakład Narodowy im. Ossolińskich, 1983, ss. 348.

Słowa kluczowe: język bułgarski; język staro-cerkiewno-słowiański; język polski; folklor bułgarski; literatura bułgarska; historia Bułgarii; stosunki polsko-bułgarskie.

Treść: F. Sławski: Język żyje, naród żyje; К. М. Куев: Старобългарски ръкописи в Полша; J. Magnuszewski: Stereotyp Polaka funkcjonujacy w świadomości Bułgarów XIX wieku; К. Мечев: За обществената актуалност на историята на литературата; H. Czajka: Folklor bułgarski i jego funkcja w średniowieczu i okresie odrodzenia; Z. Niedziela: Bułgar- 
skie odrodzenie narodowe w powieściach T. T. Jeża; K. Wierzbicka: Wspótczesna literatura bułgarska wobec historii narodowej; W. Hensel: Kultura wczesnośredniowiecznej Bułgarii $w$ świetle badań archeologicznych; П. Петров: Образуване па Бблгарската държава; T. Wasilewski: Kontrowersje wokót powstania i najstarszych dziejów państwa bułgarskiego; Б. Примов: Византия, Франкската империя и България; Я. Ив. Николова: По някои особености на културата през Птрвата и Втората българската държава (VIII$X I V$ век); С. Дамянов: България и еросе държави в ново и най-ново време; Ц. Генов: Поляците и възстановяването на българската дтржава през ХІХ век; H. Orzechowska: Jan Baudouin de Courtenay a solidarność stowiańska w okresie wojny rosyjsko-tureckiej 1877-1878. Streszczenie; J. Skowronek: Wkład emigracji polskiej w odrodzenie Bułgarii; С. Поборникова: Димитьр Благоев - основател и вожд на революиионната марксистка партия на българския пролетариат; B. Łyczko-Grodzicka: Dyplomacja polska wobec Bułgarii w okresie tworzenia Ententy Bałkańskiej. Tezy; Е. Дамянова: Българополските културни връзки (1918-1939); J. Tomaszewski: 9 września 1944 r.: powstanie ludowe czy zamach stanu; A. Koseski: Geneza i rozwój Bułgarskiej Armii Ludowej; В. Мигев: Българската сочиалистическа държава (9 IX 1944-1981 г.); Л. Огнянов: Априлският пленум на ЦК на БКП през 1956 година и сочиалистическото развитие на България.

\section{Opracowania źródłowe:}

43. Bułgarskie programy i manifesty literackie, wybór, tłum. i oprac. Wojciech Gałązka, Kraków 1983, ss. 190.

Słowa kluczowe: literatura bułgarska; bułgarskie manifesty literackie; bułgarskie programy literackie.

44. Siedem niebios i ziemia. Antologia dawnej prozy bułgarskiej, wybór, przekład, wstęp Teresa Dąbek-Wirgowa, Warszawa: Państwowy Instytut Wydawniczy, 1983, ss. 278 [2].

Słowa kluczowe: literatura starobułgarska; proza bułgarska; apokryfy bułgarskie; Fizjolog; bułgarskie średniowiecze; literatura ludowa.

\section{5}

\section{Prace zbiorowe:}

45. Od Wisły do Maricy, red. Jerzy Rusek, Instytut Słowianoznawstwa Polskiej Akademii Nauk, Towarzystwo Przyjaźni Polsko-Bułgarskiej, 1985, ss. 326 [12].

Słowa kluczowe; BRL; PRL; bułgarystyka; polonistyka; stosunki polsko-bułgarskie. 
Treść: J. Obodowski: Wspólnota gospodarcza i naukowo-techniczna między Polska i Bułgariq; А. Луканов: Плодоносно икономическо и научно-техническо сътрудничество на две соииалистически страни, на два братски народа; A. Koseski: Lata wielkiego wysitku i dorobku; J. Dynak: Literatura bułgarska w Polsce Ludowej. Bilans 40-lecia; Е. Константинова: Полската художествена литература $v$ България; П. Динеков: Българска тематика в полската литература през ХІХ век; Е. Константинова: Наблюдения над полската и българската белетристиката от 70-те години; J. Magnuszewski: Из изследванията над българската и полската хумористична проза; Е. Дамянова: Прочувания в България за историята на Полша и на полско-българските отношения; K. Woźniakowski: Wizyta pisarzy bułgarskich w Polsce w marcu 1948; O. Todorov: Bułgarski Ośrodek Kultury i Informacji w Warszawie. Z kroniki 34-letniej działalności; J. Dynak: Zasłużony jubileusz. 35-lecie Ośrodka Informacji i Kultury Polskiej w Sofii J. Rusek: W cieniu Wielkiego Brata; J. Siatkowski: Przedcyrylometodejska i starobułgarska terminologia chrześcijańska w języku polskim; L. Moszyński: Problem praojczyzny języka staro-cerkiewno-słowiańskiego w ujęciu Antoniego Kaliny - polskiego bułgarysty schyłku XIX wieku; Z. Klejn: Przepustka do klubu (przyjęcie chrześcijaństwa); J. Kwater: Wybrane zagadnienia poezji Stojana Michajłowskiego; К. Цанева: „Анхели” om Й. Словачки в контекста на българската септемврийска поезия; Г. Минчев: Средновековната и ренесансова традиция (Преводтт на Псалтира от $Я_{\mathcal{H}}$ Кохановски).

\section{Opracowania źródłowe:}

46. Dokumenty i materiały do historii stosunków polsko-bułgarskich. T. 2 (1944-1960), oprac. Wiesław Balcerak, Todor Dobrijanow, red. Wiesław Balcerak, Angeł Nakow, red. nauk. W. Balcerak, Wrocław: Zakład Narodowy im. Ossolińskich, 1985, ss. 1104 [3].

Słowa kluczowe: historia Bułgarii; 9 września 1944 r.; BRL; Todor Żiwkow; stosunki polsko-bułgarskie.

47. Naród i kultura: antologia esejów i artykułów o narodzie i kulturze bułgarskiej, wybór, wstęp i oprac. Wojciech Gałązka, Kraków: UJ, 1985, ss. 421.

Słowa kluczowe: kultura Bułgarii; bułgarska psychologia narodowa; bułgarskie manifesty; Iwan Hadżijski; Konstantyn Gyłybow; Iwan Wazow; Najden Szejtanow; bogomilstwo. 


\section{6}

\section{Prace zbiorowe:}

48. Bułgaria i Polska: rozwój społeczny i stosunki kulturalne w latach 1944-1984, red. Mieczysław Basaj, Wrocław: Zakład Narodowy im. Ossolińskich, 1986, ss. 128 [1].

Słowa kluczowe: BRL; PRL; kultura bułgarska; społeczeństwo bułgarskie; stosunki polsko-bułgarskie.

Treść: Zawiera głównie materiały z konferencji naukowej zorg. przez Instytut Historii Bułgarskiej Akademii Nauk i Instytut Słowianoznawstwa PAN, Warszawa, 23 listopada 1984 roku, częściowo tłumaczone z języka bułgarskiego. Spis tekstów: W. Migew: Geneza antyfaszystowskiego powstania 9 września 1944 r.; A. Koseski: Prawidłowości i swoistości socjalistycznego rozwoju Polski i Bułgarii; E. Damianowa: Bułgarsko-polskie kontakty kulturalne w latach 1918-1939; J. Jackowicz: Współpraca kulturalna Polski i Bułgarii w latach 1944-1984; J. Magnuszewski: Z badań nad bułgarska i polskq humorystyczna proza ludowa; H. Czajka: Folklorystyka ludowej Bułgarii; J. Dynak: Literatura bułgarska w Polsce Ludowej; J. Rusek: Język bułgarski na warsztacie polskich językoznawców; K. Woźniakowski: Początki kontaktów Związku Zawodowego Literatów Polskich i Związku Pisarzy Bułgarskich (1947-1949); S. Dziki: „Panorama Bułgarska”. Sylwetka pisma.

\section{7}

\section{Prace zbiorowe:}

49. Powstanie wrześniowe 1923 roku w literaturze bułgarskiej, red. nauk. Teresa Dąbek-Wirgowa, Warszawa: Wydawnictwa Uniwersytetu Warszawskiego, 1987, ss. 102 [1].

Słowa kluczowe: powstanie wrześniowe 1923 r., literatura bułgarska; literatura chorwacka; ekspresjonizm bułgarski; „wrześniowcy”.

Treść: J. Holzer: Kryzys parlamentaryzmu i reżymy autorytarne w Europie środkowo-wschodniej oraz południowo-wschodniej w latach dwudziestych XX wieku; T. Dąbek-Wirgowa: „Wrześniowcy - awangarda bułgarska”; G. Szwat-Gyłybowa: O czarnym nurcie w ekspresjonizmie bułgarskim; J. Sujecka: $Z$ rozważań o motywach ludowych w twórczości „wrześniowców”. Komunikat; J. Wierzbicki: Przesłanka awangardy - rewolucyjna eschatologia. 


\section{8}

\section{Słowniki i bibliografie:}

50. Radewa Sabina, Sławski Franciszek, Podręczny słownik bułgarsko-polski z suplementem, wyd. 2, T. 1 (А-повявам), Warszawa: „Wiedza Powszechna”, 1988, ss. 704 .

Słowa kluczowe: słowniki bułgarsko-polskie; język bułgarski; język polski; przekład.

51. Radewa Sabina, Sławski Franciszek, Podręczny słownik bułgarsko-polski z suplementem, wyd.2, T. 2 (повявам-яшен), Warszawa: „Wiedza Powszechna”, 1987, ss. 705-1430.

Słowa kluczowe: słowniki bułgarsko-polskie; język bułgarski; język polski; przekład.

\section{Monografie:}

52. Walkiewicz Wiesław, Stosunki bułgarsko-jugosłowiańskie 1941-1948: uwarunkowania i implikacje, Warszawa: Wydawnictwo Szkoły Głównej Gospodarstwa Wiejskiego, 1988, ss. 251.

Słowa kluczowe: stosunki bułgarsko-jugosłowiańskie; druga wojna światowa; przewrót wrześniowy; federacja bałkańska.

Treść: Studium będące próbą rekonstrukcji, oglądu i oceny stanu stosunków bułgarsko-jugosłowiańskich w latach 1941-1948, ich specyfiki, uwarunkowań i konsekwencji. Przyjęte w pracy cezury chronologiczne obejmują dwa podokresy: czas wojny (1941-1944) oraz okres 1944-1948. Autor sięga również do uwarunkowań i stanu wzajemnych relacji z okresu międzywojnia. W monografii omówiono także m.in. zagadnienia wpływu przewrotu wrześniowego na kształt wzajemnych relacji, koncepcja federacji bałkańskiej, uwarunkowania konfliktów między Jugosławią a Bułgarią po wojnie (wspólny front przeciw „wypaczeniom jugosłowiańskim”).

\section{9}

\section{Monografie:}

53. Tomaszewski Jerzy, Bułgaria 1944-1971. Trudna droga do socjalizmu, Warszawa: PWN, 1989, ss. 413 [3].

Słowa kluczowe: socjalizm w Bułgarii; BRL; 9 września 1944 r.; stosunki społeczne w Bułgarii; BKP; Todor Żiwkow; realny socjalizm. 
Treść: Autor monografii, przyjąwszy klucz chronologiczny, analizuje kolejne okresy istnienia Ludowej Bułgarii, przedstawiając ją jako drogę rozwoju, której uwieńczeniem jest tzw. rozwinięte społeczeństwo socjalistyczne w latach sześćdziesiątych. Praca skupia się zwłaszcza na przemianach politycznych, przemyśle, rolnictwie, polityce zagranicznej, sytuacji materialnej ludności, zaś ostatni rozdział poświęcono programowi na przyszłość (nowy program Bułgarskiej Partii Komunistycznej, Konstytucja 1971 roku).

\section{1}

\section{Monografie:}

54. Szwat-Gyłybowa Grażyna, W kręgu bułgarskiej groteski. O twórczości Jordana Radiczkowa, Warszawa: Slawistyczny Ośrodek Wydawniczy, 1991, ss. 119.

Słowa kluczowe: literatura bułgarska; folklor bułgarski; BRL; Jordan Radiczkow; groteska.

Treść: Monografia poświęcona twórczości współczesnego pisarza bułgarskiego - Jordana Radiczkowa. Groteska Radiczkowa interpretowana jest w aspekcie jej związków $\mathrm{z}$ bułgarską tradycją literacką, folklorem i jego literackimi transpozycjami. Jednocześnie przedmiotem badań pozostaje problematyka autotematyzmu. $\mathrm{Z}$ analizy semantyki opowiadań wynikają wnioski na temat procesu dezintegracji współczesnej kultury bułgarskiej. W tym świetle twórczość Radiczkowa nabiera znaczenia diagnozy stanu krytycznego bułgarskiej kultury narodowej w dobie totalitaryzmu.

55. Znamierowska-Rakk Elżbieta, Sprawa Tracji Zachodniej w polityce butgarskiej 1919-1947, Warszawa: Instytut Historii PAN, 1991, ss. 402 [2].

Słowa kluczowe: Tracja Zachodnia; polityka narodowościowa Bułgarii; stosunki grecko-bułgarskie; debułgaryzacja Tracji; Front Ojczyźniany.

Treść: Praca poświęcona zagadnieniom związanym ze sprawą Tracji Zachodniej w kontekście bułgarskiej polityki w latach 1919-1947. Autorka analizuje zagadnienia związane z debułgaryzacją Tracji Zachodniej i próbami jej zahamowania, opisuje walkę dyplomatyczną rządu bułgarskiego o dostęp terytorialny do Morza Egejskiego, dotyka problemu rewizjonizmu bułgarskiego w przededniu i w początkowym okresie II wojny światowej oraz okupacji bułgarskiej w Tracji Zachodniej w Macedonii Kowalskiej. Analiza sprawy Tracji Zachodniej jest umieszczona również w kontekście polityki rządu Frontu Ojczyźnianego w roku 1944. Ostatni rozdział dotyczy sprawy Tracji Zachodniej w polityce bułgarskiej w okresie przygotowań traktatu pokojowego z Bułgarią (1944-1947). 


\section{Prace zbiorowe:}

56. Polska-Bułgaria przez wieki XVII-XX: materiały z sesji Komisji Historycznej Polsko-Bułgarskiej, red. nauk. Wiesław Balcerak, Warszawa: Instytut Historii PAN, 1991, ss. 173 [3].

Słowa kluczowe: historia Bułgarii; stosunki polsko-bułgarskie; geopolityka na Bałkanach; wojny bałkańskie; bułgarskie odrodzenie narodowe.

Treść: T. Wasilewski: Rzeczpospolita Polska Litewska a Bułgarzy w dobie panowania Jana III Sobieskiego ( $w$ świetle nowych źródet); J. Weczewa: U źródeł ożywienia świadomości narodowej Bułgarów pod koniec XVII wieku; J. Wojtasik: Polski i bułgarski ruch narodowowyzwoleńczy w XIX w. i ich wzajemne stosunki; J. Skowronek: Polacy wobec bułgarskiego ruchu narodowego; M. Klimecki: Polacy w walce o niepodległość Bułgarii (1877-1878); A. Garlicka: Społeczeństwo polskie wobec kryzysu wschodniego 1875-1878; M. Tanty: Sprawa polska w czasie wojen batkańskich 1912-1913 r. (w świetle dokumentów z archiwów bułgarskich); W. Stępniak: Obecność polska w Bułgarii $i$ w innych państwach bałkańskich w czasie I wojny światowej; W. Balcerak: Problem bezpieczeństwa Polski i Bułgarii w okresie między dwiema wojnami światowymi; E. Znamierowska-Rakk: Położenie międzynarodowe Bułgarii po pierwszej wojnie światowej; E. Damianowa: Bałkańskie aspekty polskiej polityki zagranicznej (na tle stosunków między państwami bałkańskimi 1919-1939); W. Kacarkowa: Zmiany w polityce handlowej Bułgarii z zagranica w okresie międzywojennym (1919-1939); P. Cwetkow: Autorytaryzm w latach międzywojnia (na przykładzie Polski i Bułgarii); A. Koseski: Bułgaria w polityce wielkich mocarstw (1944-1947); M. Isusow: Stalin a stosunki butgarsko-jugosłowiańskie (1944-1948).

\section{2}

\section{Monografie:}

57. Gałązka Wojciech, Oswajanie skorpionów. Szkice o literaturze bułgarskiej, Kraków: „Secesja”, 1992, ss. 127.

Słowa kluczowe: literatura bułgarska; kultura bułgarska; bułgarska tożsamość kulturowa; Bułgaria a Europa.

Treść: Próba zrozumienia „zachowan’” kultury bułgarskiej w procesie przekraczania własnych granic i oswajania innych przestrzeni kulturowych, które metaforycznie nazwano skorpionami. W kręgu refleksji badawczej znalazły się rozdarcia między rodzimością i obcością, lęki przed utratą tożsamości kulturowej, gwałtowne zamknięcia, jak i równie gwałtowne otwarcia na obcość, ich rodzaje, przejawy, przyczyny i skutki 
w sferze świadomościowej i artystyczne, na obszarze zjawisk szeroko rozumianej kultury i współtworzącej ją literatury, w aspekcie aktualizowania historii.

58. Jackowicz Jerzy, Bułgaria: od rządów komunistycznych do demokracji parlamentarnej: 1988-1991, Warszawa: Instytut Studiów Politycznych PAN, 1992, ss. 100.

Słowa kluczowe: BRL; przełom demokratyczny w Bułgarii; 1989 r. w Bułgarii; opozycja antykomunistyczna w Bułgarii; partie polityczne w Bułgarii.

Treść: Praca analizująca okoliczności, w jakich miało miejsce przejście Bułgarii od rządów komunistycznych do rządów demokratów. Autor analizuje m.in. warunki powstania opozycji antykomunistycznej, wydarzenia związane $z$ utworzeniem pierwszych nieformalnych organizacji, próby zjednoczenia ruchu ludowego, walkę Związku Sił Demokratycznych o odsunięcie Bułgarskiej Partii Socjalistycznej od władzy, rozłam w ZSD i wyłonienie się trzech ugrupowań (Ruchu, Centrum, Liberałów), reakcje ugrupowań opozycyjnych wobec nowej konstytucji w roku 1991, jak również zwycięstwo ZSD w wyborach parlamentarnych i odsunięcie BPS od władzy.

\section{3}

\section{Monografie:}

59. Kaczmarek Urszula, Dzieje Polaków na ziemiach bułgarskich, Poznań: „Ars Nova”, 1993, ss. 120 [3].

Słowa kluczowe: emigracja polska w Bułgarii; Polonia bułgarska; stosunki polsko-bułgarskie; kolonia polska w Bułgarii.

Treść: Zarys dziejów polskiej emigracji na ziemiach bułgarskich. Autorka zwraca uwagę na cywilizacyjną rolę emigracji polskiej na ziemiach bułgarskich (w oświacie, kulturze, gospodarce, medycynie, służbie zdrowia), jak również opisuje proces powstania, rozwoju i organizacji kolonii polskiej w Bułgarii w XIX w. Ostatni rozdział poświęcony jest Polonii bułgarskiej podczas drugiej wojny światowej i współczesnej Polonii bułgarskiej.

\section{Prace zbiorowe:}

60. Najstarsze druki cerkiewnosłowiańskie i ich stosunek do tradycji rękopiśmiennej: materiały z sesji, Kraków 7-10 XI 1991, red. Jerzy Rusek, Wiesław Witkowski i Aleksander Naumow, Kraków: Instytut Filologii Słowiańskiej UJ, 1993, ss. 350 [1]. 
Słowa kluczowe: druki cyrylickie w Polsce; język staro-cerkiewno-słowiański; zabytki rękopiśmiennictwa; tradycja rękopiśmienna.

Treść: P. Buchwald-Pelcowa: Rola książki $w$ drugiej połowie XV w.; A. Naumow: Teologiczny aspekt druku (na materiale najstarszych wydań cerkiewnosłowiańskich); Д. Дунков: Книгата Рут в славянската ръкописна традиция и в Острожската Библия; E. Solak: Biblia cerkiewnosłowiańska a nowobułgarskie przekłady Pisma św. - wyzwanie czy inspiracja?; A. Kaszlej: Wplyw cerkiewnosłowiańskiej ksiażki drukowanej na rękopiśmienna (na podstawie zbiorów Biblioteki Narodowej w Warszawie); M. Błońska, H. Bułhak: Na tropach książek cyrylickich wydawanych w państwie polsko-litewskim w XV-XVIII w. Próba charakterystyki; M. Pidłypczak-Majerowicz: Cerkiewnosłowiańskie druki bazyliańskie w powojennych zbiorach bibliotek polskich; Д. Дунков, Д. Иванова: Старопечатните славянски книги в пловдивската Народна библиотека „Иван Вазов"; O. Narbutt: Wybrane zagadnienia terminologiczne zwiazane z charakterystyka najstarszych druków cerkiewnosłowiańskich.

\section{6}

\section{Monografie:}

61. Sujecka Jolanta, Obraz wielkiej przemiany w poezji bułgarskiej (1918-1925), Warszawa: Slawistyczny Ośrodek Wydawniczy, 1996, ss. 110.

Słowa kluczowe: poezja bułgarska; manifesty literackie; prawosławie; Christo Smirnenski; Geo Milew; Nikola Furnadżijew; Asen Razcwetnikow; Łamar.

Treść: Przedmiotem badań jest świat poetycki pięciu bułgarskich poetów: Christo Smirnenskiego, Geo Milewa, Nikoly Furnadžijewa, Asena Razcwetnikowa i Łamara. Bibliografie poetów i teksty traktowane są jako dokument świadomościowy pozwalający dotrzeć do istoty przeżywania wielkiej przemiany świata. Przemiana, rozumiana jako odnowa wartości, w tekstach poetyckich, manifestach i artykułach przybrała kształt trzech hipostaz, dla których zaproponowano nazwy: homo politicus, homo ethicus i homo barbarus. Ich konfrontacja jako użytecznych fikcji badawczych prowadzi do zarysowania systemu aksjologicznego warstwy kulturotwórczej epoki przełomu. Jednocześnie jest próbą uchwycenia specyfiki prawosławnego kręgu kultury.

\section{7}

\section{Monografie:}

62. Solak Elżbieta, Nowobułgarska Biblia i jej język, Kraków: Wydawnictwa UJ, 1997, ss. 132 [4]. 
Słowa kluczowe: język bułgarski; Biblia; przekłady Biblii; odrodzenie narodowe.

Treść: Praca podejmuje temat miejsca i roli przekładu Biblii w procesie tworzenia nowobułgarskiego języka literackiego na tle problemów związanych z kształtowaniem się nowożytnej świadomości narodowej, społecznej i religijnej. Autorka analizuje zjawisko nagłego wzrostu zainteresowania tłumaczeniem Pisma Św., które było charakterystyczne dla bułgarskiego Odrodzenia narodowego.

\section{3. Żmigrodzki Marek, Przeobrażenia polityczno-ustrojowe i Sąd Konstytu- cyjny w Bułgarii, Lublin: Wydawnictwo UMCS, 1997, ss. 196.}

Słowa kluczowe: bułgarskie partie polityczne; sądownictwo konstytucyjne; postkomunizm; demokracja; Sąd Konstytucyjny.

Treść: Celem pracy jest dokonanie rekonstrukcji funkcjonowania Sądu Konstytucyjnego w życiu politycznym Bułgarii, czyli ukazanie organizacji, zakresu działania i pozycji ustrojowej Sądu oraz samych procedur kontroli konstytucyjności prawa. Autor bada, na ile sądownictwo konstytucyjne w Bułgarii odpowiada standardom stawianym tego typu sądownictwu w ustabilizowanych demokracjach parlamentarnych, jak i w innych państwach postkomunistycznych oraz jaką rolę spełniło w pierwszym okresie przemian ustrojowych.

\section{8}

\section{Monografie:}

64. Giza Antoni, Państwa bałkańskie wobec kwestii macedońskiej w latach 1978-1918, Szczecin: Wydawnictwa Naukowe US, 1998, ss. 205 [1].

Słowa kluczowe: kraje bałkańskie; Macedonia; macedoński ruch narodowowyzwoleńczy; kwestia macedońska; stosunki bułgarsko-macedońskie; powstanie ilindeńskie; wojny bałkańskie; pierwsza wojna światowa.

Treść: Praca jest kolejną próbą ustosunkowania się do kwestii macedońskiej, ściśle nawiązującą do monografii A. Gizy „Ziemie macedońskie na przełomie XIX i XX wieku", w której, według autora, zbyt słabo wyartykułowany został związek występujący w tym okresie pomiędzy macedońskim ruchem narodowowyzwoleńczym i dążeniami bułgarskimi zarówno państwa bułgarskiego, jak i ludności na jego obszarze oraz ludności pozostającej pod panowaniem tureckim, a później greckim. Praca ma układ chronologiczno-problemowy. W pierwszym rozdziale przedstawiono położenie społeczno-ekonomiczne Macedonii na przełomie XIX i XX wieku. Rozdział II omawia powstanie ilindeńskie. W III i IV rozdziale omówiono kwestię macedońską podczas wojen bałkańskich oraz pierwszej wojny światowej. 
65. Krzepkowski Stanisław, Bałkany, Bułgaria, Polska. Studium z historii powszechnej XIX i XX wieku, Kielce: „Bog \& Art”, 1998, ss. 135.

Słowa kluczowe: Bałkany; historia Bułgarii; stosunki polsko-bułgarskie; zjednoczenie Bułgarii; społeczeństwo bułgarskie.

Treść: Zbiór tekstów dotyczących dziejów Bułgarii i innych krajów bałkańskich w XIX i XX wieku. Autor porusza m.in. kwestie dotyczące Rzeczpospolitej i Bułgarii w XVII w., problemu bułgarskiego w polskiej myśli politycznej i społecznej w kraju i wśród emigracji w XIX wieku, roli Polaków w bałkańskich problemach narodowych w XIX i XX w, zjednoczenia Księstwa Bułgarii i Rumelii Wschodniej w procesie tworzenia państw narodowych na Bałkanach czy znaczenia islamu w krajach bałkańskich dawniej i obecnie. Część tekstów w języku angielskim.

\section{9}

\section{Monografie:}

66. Jackowicz Jerzy, Partie opozycyjne w Bułgarii w 1944-1948, Warszawa: Instytut Studiów Politycznych PAN, 1999, ss. 250.

Słowa kluczowe: partie polityczne w Bułgarii; Bułgaria a ZSRR; opozycja polityczna; Front Ojczyźniany; komunizm.

Treść: Praca ukazuje dramatyczne losy demokratycznej opozycji w Bułgarii w pierwszych latach powojennych. Przedstawia proces kształtowania się partii opozycyjnych wobec zdominowanego przez komunistów rządu Frontu Ojczyźnianego, ich walkę o demokratyzację bułgarskiego życia politycznego oraz rozbicie i całkowitą likwidację opozycji, znamionującą zakończenie procesu budowy systemu totalitarnego. Losy partii opozycyjnych zostały zaprezentowane na szerokim tle międzynarodowym, ze szczególnym uwzględnieniem wpływu ZSRR i mocarstw zachodnich na problemy wewnętrzne Bułgarii.

67. Klejn Zbigniew, Polskie ślady w budowie nowożytnej Bułgarii 1887-1914, Łowicz: WSHP, 1999, ss. 449.

Słowa kluczowe: Polacy za granicą; architektura bułgarska; stosunki polsko-bułgarskie; historia Bułgarii.

Treść: Praca dotycząca wkładu Polonii w nowożytne dzieje Bułgarii w latach 1887-1914, stanowi jednocześnie zapis losów Polaków na przełomie XIX i XX wieku oraz ukazuje nieznane karty z dziejów powszechnych emigracji polskiej i Polonii. Autor prezentuje zarys wzajemnych polsko-bułgarskich relacji kulturalnych (osób i instytucji), pisze o wkładzie Polonii w rozwój Bułgarii w tym okresie. Porządkuje także wiedzę 
o emigracji polskiej, prezentując losy wielu Polaków często zapomnianych lub takich, których znane dotąd życiorysy urywały się po przybyciu na Bałkany.

\section{Prace zbiorowe:}

68. IV Kolokwium Slawistyczne Polsko-Bułgarskie: materiały sesji naukowej zorganizowanej przez Uniwersytet im. Adama Mickiewicza w Poznaniu $i$ Uniwersytet im. Paisija Chilendarskiego w Płowdiwie, Poznań, 15-16 X 1992, red. Jerzy Świdziński, Poznań: „Polinfo”, 1999, ss. 156.

Słowa kluczowe: język bułgarski; język polski; języki słowiańskie; literatura bułgarska; literatury słowiańskie.

Treść: Б. Ганчева: За националната самооценка на българския възрожденски и следосвобожденски автор; U. Grzelak: Przybyszewskiego portret wielokrotny; Д. Иванова: Полонизми в българския книжовен език през възрожденската епоха; О. Сапарев: Четенето като диалогично самообщуване; J. Sydor: Tетаtyka słowiańska w czasopiśmie poznańskim „Lech” (1878-1879); Е. Свидзиньский, В. Василенко: „Кирджали”: герой в системе движущихся координат. Вводная част: Разбойник? Мятежник? Беглец?

\section{1}

\section{Monografie:}

69. Sujecka Jolanta, Ikona domu, Warszawa: Slawistyczny Ośrodek Wydawniczy, 2001, ss. 216.

Słowa kluczowe: literatura bułgarska; literatura rosyjska; literatura serbska; Geo Milew; Nikoła Furnadżijew; Bułgaria słowiańska; Bułgaria orientalna.

Treść: Praca rekonstruuje zagadnienie stosunku przedstawicieli elity artystycznej do tego, co swoje i co obce w kulturze sąsiadów oraz w Europie uniwersalnych wartości. Przedmiotem interpretacji są biografie oraz twórczość Władimira Majakowskiego, Geo Milewa, belgradzkich nadrealistów w okresie istnienia tego ruchu, twórczość Siergieja Jesienina i Nikoły Furnadżijewa oraz program rosyjskich euroazjatów, koncepcje Bułgarii słowiańskiej i Bułgarii orientalnej.

\section{Prace zbiorowe:}

70. VIII Kolokwium Slawistyczne Polsko-Bułgarskie, red. nauk. Mariola Walczak-Mikołajczakowa, Gniezno: TUM, 2001, ss. 206. 
Słowa kluczowe: duchowość chrześcijańska; język bułgarski; język macedoński; stosunki polsko-bułgarskie; Slavia Latina; Slavia Orthodoxa.

Treść: Aleksander W. Mikołajczak, M. Walczak-Mikołajczakowa: Latinitas i Cyrilianitas - poszukiwanie duszy Europy; A. Naumow: Język - deklaracja przynależności czy narzędzie?; I. Lis: Świętość i święty w słowiańskiej tradycji ludowej; Д. Иванова: Конщепции и модели за общославянски книжовен език в културната история на славянските народи в периода на националното им възраждане; E. Solak: Gramatyka braci Cankowów - problemy i perspektywy badawcze; W. Jóźwiak: Bułgaria oczyma XIX-wiecznego polskiego misjonarza.

71. Między kultura „niską" a „wysoka”: zjawiska językowe, literackie, kulturowe. Pamięci prof. dr hab. Teresy Dąbek-Wirgowej. Materiały z Konferencji Naukowej Łódź, 28-29 marca 2000, red. M. Korytkowska, Z. Darasz, G. Minczew, Łódź: Archidiecezjalne Wydawnictwo Łódzkie, 2001, ss. 392.

Słowa kluczowe: język bułgarski; literatura bułgarska; Słowianie Południowi; folklor bułgarski; bułgarskie odrodzenie narodowe.

Treść: Część I. Literatura. K. Bachnewa: „Новата Обетована земя на българската поезия" или за краткия исторически очерк „Българска литература” на Боян Пенев; C. Canew: Единство на ниската и висока култура в старобългарската литература през IX-X век; H. Dolata: Swojskość i uniwersalność epigramatów Radoja Ralina; W. Gałązka: Granice przestrzeni, granice czasu u Jordana Jowkowa; C. Juda: Dziejów prostaczka ciąg dalszy. Uwagi na marginesie; M. Iwanowa-Girginowa: Българската драма - кръстопғт на две култури; H. Karpińska: Profesor Teresa Dąbek-Wirgowa jako tłumaczka literatury bułgarskiej; E. Konstantinowa: Фантастиката в модерността и пост-модерността. Наблюдения над българската художествена проза; G. Minczew: Między sacrum a profanum w piśmiennictwie południowosłowiańskim. Legenda o świętym Jerzym i diable; K. Wrocławski: Folklor jako instrument polityki na pograniczach etnicznych; J. Sujecka: Pojęcie Macedonii w wybranych dokumentach, publicystyce i tekstach folkloru z pierwszej połowy XX wieku. Od idei słowiańskiej jedności do federacji bałkańskiej; G. Szwat-Gyłybowa: Bojan Obretenow i jego rekapitulacja ideologii bułgarskiego odrodzenia narodowego;

\section{2}

\section{Słowniki i bibliografie:}

72. Głogowski Piotr, Moroz-Grzelak Lilla, Stefański Michał, Bibliografia słowianoznawstwa polskiego za lata 1996-2000. Słowiańszczyzna zachodnia 
i południowa, Warszawa: Instytut Slawistyki PAN: Slawistyczny Ośrodek Wydawniczy, Instytut Filologii Słowiańskiej UW, 2002, ss. 221.

Słowa kluczowe: bibliografie; słowianoznawstwo; Słowiańszczyzna zachodnia; Słowiańszczyzna południowa.

73. Rękopisy cerkiewnosłowiańskie w Polsce: katalog, oprac. Aleksander Naumow oraz Andrzej Kaszlej przy współpr. Ewy Naumow i Jana Stradomskiego, Kraków: „Scriptum”, 2002, ss. 517.

Słowa kluczowe: księgi liturgiczne; katalogi; prawosławie; rękopisy staro-cerkiewno-słowiańskie w Polsce.

\section{Materiały źródłowe:}

74. Ziemscy aniołowie - niebiańscy ludzie: anachoreci w bułgarskiej literaturze i kulturze, wybór i wstęp Georgi Minczew, redakcja Galia Simeonova-Konach, Białystok: „Orthdruk”, 2002, ss. 135 [1].

Słowa kluczowe: prawosławie; eremici w Bułgarii; literatura bułgarska; literatura chrześcijańska; święci; błogosławieni.

Treść: Publikacja poświęcona funkcjonowaniu anachoretów w bułgarskiej kulturze i literaturze. Pustelnicy do dziś są otaczani w Bułgarii największym kultem, tak w wydaniu oficjalnym, jak i ludowym. Obok średniowiecznych żywotów i hymnów, w zbiorze znalazły się także żywoty współczesne i legendy ludowe. Lekturę tekstów z odmiennego obszaru kulturowego ułatwia obszerne słowo wstępne i noty historyczne do każdego tekstu. Wydawnictwo ma charakter popularny, ale doskonale może służyć studentom i wykładowcom bułgarystyki. Autorem pomysłu wydania antologii polskich przekładów tekstów o bułgarskich świętych, wyboru oraz wstępu jest Georgi Minczew. Nad przekładami pracowali bułgaryści łódzcy i krakowscy.

\section{3}

\section{Podręczniki:}

75. Tanty Mieczysław, Bałkany XX wieku. Dzieje polityczne, Warszawa: Książka i Wiedza, 2003, ss. 418 [1].

Słowa kluczowe: państwa bałkańskie; monarchie bałkańskie; panowanie tureckie; pierwsza wojna światowa; druga wojna światowa; komunizm.

Treść: Synteza dziejów Bałkanów w XX w. Zawiera między innymi opis powstania pierwszych nowożytnych państw bałkańskich, a następnie monarchii bałkańskich na 
przełomie XIX i XX wieku, czy też opis końca kilkusetletniego panowania tureckiego. Wiele miejsca w książce zajmują wydarzenia na półwyspie podczas pierwszej i drugiej wojny światowej, a także w okresie dominacji komunistycznej z uwzględnieniem szczególnego przypadku jugosłowiańskiego.

\section{Monografie:}

76. Giza Antoni, Bułgaria i problem macedoński od początku XVIII do lat trzydziestych XX wieku, Szczecin, 2003, ss. 312.

Słowa kluczowe: bułgarski ruch narodowowyzwoleńczy; Macedonia; panowanie tureckie; powstanie ilindeńskie; powstanie preobrażeńskie; wojny bałkańskie; kwestia macedońska.

Treść: Monografia ma układ chronologiczno-problemowy i składa się z sześciu rozdziałów. W pierwszym i drugim przedstawiono sytuację ziem bułgarskich pod panowaniem tureckim w XVIII wieku oraz ich rozwój w pierwszej połowie XIX wieku wraz z działalnością ruchu narodowowyzwoleńczego. W rozdziale trzecim, po zaprezentowaniu ogólnej sytuacji w Bułgarii wyzwolonej spod panowania tureckiego, przedstawione zostały przyczyny, przebieg i następstwa powstań ilindeńskiego i preobrażeńskiego z 1903 roku. W rozdziale czwartym i piątym omówiono wojny bałkańskie lat 1912-1913 oraz rozwój kwestii macedońskiej przed pierwszą wojną światową, podczas niej i po wojnie. Kwestie ogólnie znane pominięto, koncentrując się na sprawie macedońskiej.

\section{Juda Celina, Pod znakiem BRL-u. Kultura i literatura bułgarska w pułapce} ideologii, Kraków: „Universitas”, 2003, ss. 225.

Słowa kluczowe: BRL; kultura bułgarska; Todor Żiwkow; Nikoła Georgijew; inteligencja bułgarska; proza bułgarska.

Treść: W pracy podjęto próbę wielostronnego opisu zjawisk, które stanowiły o tożsamości literatury i kultury w czasach totalitarnej Bułgarskiej Republiki Ludowej. Zamiarem autorki było odtworzenie stanu i kondycji świadomości kształtowanej przez beerelowskie universum oraz odnalezienie kulturowych uzasadnień, głęboko zakorzenionych w rodzimej tradycji, do których nowa epoka najczęściej się odwoływała.

78. Minczew Georgi, Święta księga - ikona - obrzęd. Teksty kanoniczne i pseudokanoniczne a ich funkcjonowanie w sztuce sakralnej i folklorze prawosławnych Słowian na Bałkanach, Łódź: Wydawnictwo UŁ, 2003, ss. 223.

Słowa kluczowe: Słowianie Południowi; średniowiecze; prawosławie; liturgia; obrzędy ludowe; sztuka sakralna; chrześcijaństwo ludowe. 
Treść: Autor zajął się trzema problemami z zakresu słowiańskiej kultury prawosławnej: liturgią, sztuką sakralną oraz obrzędowością ludową. Wykraczając poza warsztat filologiczny, zajmuje się ich tekstami kulturowymi - od tekstu pisanego po obrzędowość i wierzenia ludowe - oraz wzajemnym oddziaływaniem i współegzystencją w południowosłowiańskiej przestrzeni religijnej. Kolejne rozdziały poświęcono kanonicznej i niekanonicznej realizacji następujących tematów: praktyk procesyjnych na wypadek klęsk żywiołowych, misterium liturgii, spełniającemu się w planie realnym, legendzie o św. Sisiniju, kultom świętych wojowników - Dymitra i Jerzego, bliźniaczym kultom św. św. Petki i Nedelji. Mimo iż wykorzystane źródła powstawały pomiędzy X a XIX w., a komentowane są także współczesne zjawiska folklorystyczne, zasadniczo praca dotyka kultury średniowiecznej. Kultury prawosławnej nie ogranicza się w książce do sfery teologicznej, fenomenu monastycyzmu i ikonografii, ale jako równorzędne elementy tej kultury bada się - obok misterium sakralnego i ikony - przejawy chrześcijaństwa ludowego.

\section{Prace zbiorowe:}

79. Polska - Bułgaria w Europie Środkowej i Południowo-Wschodniej w wiekach XVII-XX: podobieństwa, różnice, uwarunkowania. Materiały sesji Polsko-Bułgarskiej i Bułgarsko-Polskiej Komisji Historycznych, red. nauk. Wiesław Balcerak, Warszawa: Instytut Historii PAN; Łowicz: MWHP, 2003, ss. 303.

Słowa kluczowe: federalizm; Słowianie Południowi; Bizancjum; federacja bałkańska; stosunki polsko-bułgarskie.

Treść: E. Znamierowska-Rakk: In memoriam. Profesor Mito Isusow (1928-1999); R. Komsałowa: Bizantyński „ekumenizm”, prawosławie i idea bałkańskiej federacji; E. Weczewa: Bałkańska inteligencja katolicka w XVII wieku; E. Weczewa: Świat słowiański a koncepcja polityczna Rzymu w XVII wieku; S. Popowa-Totewa: Skarby sztuki chrześcijańskiej bułgarskiego odrodzenia $w$ świetle analizy ikon $w$ Trjawna; E. Weczewa: Idea państwa ogólnosłowiańskiego w XVII wieku; D. Kałkandżijewa: Wpływ bałkańskiego prawosławia i polskiego katolicyzmu na rosyjskie życie religijne i społeczne XVII wieku; I. Todew: Idea narodowa a Bułgarzy 1762-1912; A. Wierzbicki: Wschód - Zachód - Stowiańszczyzna - Polska w myśli historycznej i politycznej polskiego romantyzmu; E. Znamierowska-Rakk, Bałkańskie koncepcje federacyjne. Nadzieje i zagrożenia (schyłek XVII wieku - koniec I wojny światowej); P. Żurek: Plan federacji bałkańskiej a przyczyny dymisji księcia Adama Jerzego Czartoryskiego ze stanowiska pełniacego obowiazki ministra spraw zagranicznych Rosji (1804-1806); I. Todew: Idee federacyjne dr. Stojana Czomakowa; Z. Klejn: O poszerzenie badań nad udziałem Polaków $w$ realizacji bułgarskich aspiracji narodowych $w$ XIX wieku; K. Manczew: Federalizm jako alternatywa mocarstwowości, hegemonizmu i nacjonalizmu na Bat- 
kanach; L. Ljubenowa: Ekonomiczne podstawy życia Kościoła prawosławnego w Butgarii (1918-1944); P. Stawecki: Z badań nad zwiazkami polsko-bułgarskimi w latach 1918-1939; E. Damianowa: Komunikacja północ-południe a problem budowy mostu na Dunaju w latach dwudziestych i trzydziestych XX wieku; A. Garlicka: Wielka Brytania a powstanie Ententy Bałkańskiej 1933-1934; A. Garlicka: Wielka Brytania wobec idei integracji państw bałkańskich w końcu lat trzydziestych XX wieku; W. Stojanowa: Bułgarska polityka kulturalna w Macedonii Wschodniej i Tracji Zachodniej podczas II wojny światowej; W. Toszkowa: Bułgaria i polityka bałkańska Stanów Zjednoczonych (1 września 1939 - 28 października 1944 r.); N. Christowa: Władza i inteligencja w Bułgarii po II wojnie światowej; I. Baewa: Modele kultury politycznej w powojennej Polsce i Bułgarii; S. Aleksandrowa-Gonczewa: Zmiany w układzie sit międzynarodowych w latach dziewięćdziesiątych XX wieku a bułgarska kultura.

\section{4}

\section{Słowniki i bibliografie:}

80. Rękopisy cerkiewnosłowiańskie w Polsce: katalog, oprac. Aleksander Naumow oraz Andrzej Kaszlej, przy współpr. Ewy Naumow i Jana Stradomskiego wyd. II zmienione, Kraków: „Scriptum”, 2004, ss. 569.

Słowa kluczowe: księgi liturgiczne; prawosławie; rękopisy staro-cerkiewno-słowiańskie w Polsce.

\section{Monografie:}

81. Moroz-Grzelak Lilla, Aleksander Wielki a macedońska idea narodowa: słowiańskie losy postaci antycznej, Warszawa: Towarzystwo Naukowe Warszawskie, Instytut Slawistyki PAN, 2004, ss. 168.

Słowa kluczowe: Aleksander Wielki; literatury słowiańskie; literatura grecka; literatura macedońska; macedońska idea narodowa.

Treść: Praca analizuje znaczenie postaci Aleksandra Wielkiego w kształtowaniu macedońskiej idei narodowej. W procesie kreowania Aleksandra na niezwykłego bohatera i utrwalania jego wizerunku w świadomości społecznej dużą rolę odegrała najstarsza literatura, sięgająca do czasów współczesnych temu władcy. Odgłosy recepcji dzieła antycznych odnaleźć można także w piśmiennictwie słowiańskim. Autorka poświęca kolejne rozdziały postaci Aleksandra Wielkiego w piśmiennictwie starożytnym, antycznym opowieściom o Aleksandrze Wielkim oraz ich serbskiej redakcji, funkcjom mitu Aleksandra Wielkiego w dziewiętnastowiecznym piśmiennictwie obszaru bułgarsko-macedońskiego oraz macedońskiemu mitowi Aleksandra Wielkiego w XX wieku. 
82. Rubacha Jarosław, Bułgarski sen o Bizancjum. Polityka Bułgarii w latach 1878-1913, Warszawa: „Neriton”, 2004, ss. 387 [17].

Słowa kluczowe: historia Bułgarii; polityka zagraniczna; dyplomacja; Bizancjum.

Treść: Publikacja prezentuje założenia i realizację bułgarskiej polityki zagranicznej, której celem miało być stworzenie państwa obejmującego swymi granicami wszystkie ziemie zamieszane przez ludność bułgarską. Omówione zostały także kolejne wojny toczone przez Bułgarię przeciwko Turcji i innym bałkańskim sąsiadom.

83. Walczak-Mikołajczakowa Mariola, Piśmiennictwo katolickie w Bułgarii: język utworów II połowy XVIII wieku, Poznań: Wydawnictwo Naukowe UAM, 2004, ss. 253 [1].

Słowa kluczowe: język bułgarski; literatura bułgarska; słownictwo; stylistyka; literatura katolicka.

Treść: Publikacja zawiera podstawowe informacje z dziejów kościoła katolickiego w Bułgarii. Ma odpowiedzieć na pytanie, czym charakteryzował się język utworów pisanych przez bułgarskich katolików w okresie, gdy nie istniała jeszcze znormalizowana bułgarszczyzna literacka. Autorka bada twórczość biskupów płowdiwskich, Pawła Gajdadżijskiego Duwanlii (1714-1804) i Piotra Kowaczewa (1720-1796). Uwzględnia także utwory anonimowe pochodzące $\mathrm{z}$ tego okresu. Cenne materiały źródłowe stanowią zebrane i odczytane przez autorkę rękopisy przechowywane w bibliotekach narodowych w Sofii i Płowdiwie, które zamieszczono w dołączonej do pracy Antologii.

\section{Prace zbiorowe:}

84. Idee wspólnotowe Słowiańszczyzny, red. Aleksander W. Mikołajczak, Witold Szulc, Bogusław Zieliński, Poznań: Wydawnictwo Naukowe UAM; [Gniezno]: Collegium Europaeum Gnesnense, 2004, ss. 310.

Słowa kluczowe: języki słowiańskie; Słowianie; słowianofilstwo; narody słowiańskie; bułgarskie odrodzenie narodowe.

Treść: Dwuczęściowe studium na temat Słowiańszczyzny w aspekcie historycznym i lingwistycznym. Autorzy zastanawiają się nad tradycjami słowiańskimi m.in. Poznania i Wielkopolski w XIX wieku, mitami i rozpadem SFRJ, genezą idei słowiańskiej w Rosji XVII-XX wieku oraz macedońską ideą wspólnotową. Artykuły: A. W. Mikołajczak: Łacińska tożsamość Stowiańszczyzny; A. Kijas: Idea stowiańska w Rosji w XVII-XX wieku (do 1917 roku); W. Jóźwiak: Idee wspólnotowe Słowiańszczyzny w koncepcji G. S. Rakowskiego; J. Paszkiewicz: Włochy wobec południowosłowiańskiej idei wspólnotowej w latach 1914-1918; E. Znamierowska-Rakk; Geneza rokowań bułgarsko-jugosłowiańskich na temat Federacji Słowian Południowych (dalej - FSP) i dwustronnego sojuszu; I. Stawowy-Kawka: 
Macedońskie idee wspólnotowe - Metodija Andonov-Ćento (1902-1957); D. Iwanowa: Spóźniona próba utworzenia ogólnosłowiańskiego języka literackiego w końcu XIX w.: echo bułgarskiego Odrodzenia; L. Miodyński: Integralizm i separatyzm w macedońskim procesie samostanowienia kulturalnego; G. Simeonowa-Konach: Idea słowiańska a egzotyczny Inny; M. Wojtczak: Święci Cyryl i Metody w słowianofilstwie bułgarskim.

\section{5}

\section{Monografie:}

85. Szwat-Gyłybowa Grażyna, Haeresis bulgarica w bułgarskiej świadomości kulturowej XIX i XX wieku, Warszawa: Slawistyczny Ośrodek Wydawniczy, 2005, ss. 334 [1].

Słowa kluczowe: bogomilstwo; manicheizm; literatura bułgarska; kultura bułgarska; mitologia narodowa.

Treść: Studium z zakresu historii idei, podejmujące nieopracowaną dotąd problematykę adaptacji średniowiecznej gnozy bogomilskiej do potrzeb nowoczesnego i ponowoczesnego dyskursu tożsamościowego Bułgarów. Obiektem badań stały się tu różnorodne teksty kultury bułgarskiej, które w szczególny sposób przysłużyły się rewitalizacji bogomilstwa. Badany materiał pozwolił na ujawnienie związków między strategiami mitologizacji bogomilstwa w nowoczesnej kulturze bułgarskiej a preferowanymi przez twórców - i często pozostającymi ze sobą w konflikcie - projektami bułgarskiej modernitas. Osłonięcie mechanizmów manipulowania przeszłością umożliwiło uchwycenie całości procesu formowania bogomilstwa jako „miejsca pamięci” zbiorowej Bułgarów.

86. Znamierowska-Rakk Elżbieta, Federacja Słowian południowych w polityce Bułgarii po II wojnie światowej: korzenie, próby realizacji, upadek, Warszawa: „Neriton”, 2005, ss. 492 [2].

Słowa kluczowe: federalizm; Słowianie południowi; zjednoczenie Macedonii; stosunki bułgarsko-jugosłowiańskie.

Treść: Monografia porusza problematykę idei federacyjnej Słowian południowych, która w decydującym stopniu określała stosunki bułgarsko-jugosłowiańskie w końcowej fazie II wojny światowej i w pierwszych latach po jej zakończeniu. Autorka przedstawia kontekst historyczny idei federacyjnej na Bałkanach, którego korzenie sięgają schyłku XVIII i początku XIX wieku. Dotyka także kwestii sporów wokół zjednoczenia Macedonii w początku lat czterdziestych XX wieku. Analizuje meandry procesu zbliżenia bułgarsko-jugosłowiańskiego w latach 1944-1945, apogeum zbliżenia południowosłowiańskiego w latach 1947-1448, a także zmierzch i upadek koncepcji federacji Słowian południowych w 1948 roku. 


\section{6}

\section{Monografie:}

87. Malinowski Andrzej, Kwestia macedońska w Bułgarii w latach 1878-1918, Toruń: „Mado”, 2006, ss. 254.

Słowa kluczowe: Bałkany; Macedonia; problem macedoński; polityka bułgarska; bułgarskie ruchy społeczne.

Treść: Książka ukazuje reakcje mocarstw europejskich na wydarzenia rozgrywające się na Półwyspie Bałkańskim oraz przedstawia kroki, jakie państwa te podejmowały w celu rozwiązania jednego z elementów wielkiej sprawy wschodniej, tzw. problemu macedońskiego.

88. Wojtczak Marcin, Mit cyrylo-metodejski. W kręgu bułgarskiej idei narodowej, Poznań: Wydawnictwo UAM, 2006, ss. 216 [3].

Słowa kluczowe: Cyryl i Metody; kultura bułgarska; język bułgarski; prawosławie; odrodzenie narodowe.

\section{Prace zbiorowe:}

89. Znane i nieznane przestrzenie w języku i kulturze Bułgarii: materiały z międzynarodowej konferencji studenckiej, Poznań, 3-4 marca 2006 roku, red. nauk. Mariola Walczak-Mikołajczakowa, Kristina Chichikova, Poznań: „Piktor”, 2006, ss. 144.

Słowa kluczowe: folklor bułgarski; język bułgarski; literatura bułgarska; historia Bułgarii.

Treść: K. Krzeszewska: Literatura ludowa w Polsce i w Bułgarii; N. Pawlik: Antychryst Emiliana Stanewa - problematyka konwencji gatunkowej; M. Jankowska: „Łazarz i Jezus" Emiliana Stanewa w tłumaczeniu Teresy Dąbek-Wirgowej-rozważania nad stylizacja językową; A. Szafrańska: Postać Łazarza we wspótczesnej literaturze bułgarskiej (na przykładzie twórczości Emiliana Stanewa i Jordana Radiczkowa); N. Cybart: Refleksje na temat istoty poezji w utworach Wisławy Szymborskiej i Błagi Dimitrowej; A. Szudrowicz: Kategoria piękna w dramacie Jordana Jowkowa „Albena”; E. Szperlik: Wokół bułgarskiego socrealizmu - wybrane utwory I. Martinowa; J. Janusz: O istotach demonicznych $w$ bułgarskiej tradycji ludowej; P. Lyanguzov: Православието на Балканите, или това, което проижхожда от сърието; Ł. Mysielski: Ciało i krew jako życiodajny pokarm południowosłowiańskich demonów. Różni i równi - status społeczności romskiej w Bułgarii. 


\section{Opracowania źródłowe:}

90. Apokryfy i legendy starotestamentowe Słowian Południowych, wybór i red. Georgi Minczew, Małgorzata Skowronek, przedm. Georgi Minczew, Dejan Ajdačić, Kraków: Wydawnictwo Uniwersytetu Jagiellońskiego, 2006, ss. 386 [1].

Słowa kluczowe: Biblia; Stary Testament; apokryfy słowiańskie; legendy i podania; Słowianie Południowi.

Treść: Praca stanowiąca oryginalne opracowanie źródłowe, wypełniające lukę w polskojęzycznej - i nie tylko - literaturze zarówno w dziedzinie apokryfów Starego Testamentu, jak i wiedzy o kulturze Słowian Południowych. Dzięki przyjęciu odmiennej perspektywy kulturowej, ukształtowanej przez prawosławie, antologia łączy literaturę pseudokanoniczną z zapisami ustnych przekazów ludowych, które wiążą się z nimi strukturalnie i tematycznie. Praca dzieli się na dwie części. W pierwszej przedstawione zostają apokryfy starotestamentowe, w drugiej - legendy folklorystyczne. Komentarz prezentuje natomiast relacje literatury pseudokanonicznej z postbizantyjską ikonografią.

91. Historia Bułgarii 1870-1915: materiały źródłowe z komentarzami. T. 1, Polityka międzynarodowa, oprac. Jarosław Rubacha, Andrzej Malinowski, Antoni Giza, Warszawa: „Neriton”, 2006, ss. 179 [6].

Słowa kluczowe: polityka Bułgarii; historia Bułgarii; stosunki międzynarodowe; dyplomacja; Półwysep Bałkański.

Treść: Pierwsze tego typu wydawnictwo w polskiej historiografii. Autorzy dokonali wyboru i tłumaczenia najważniejszych dokumentów dotyczących historii politycznej Bułgarii na przełomie XIX i XX i opatrzyli je fachowymi komentarzami ułatwiającymi czytelnikowi zrozumienie zawiłych kwestii dyplomatycznych.

92. Złota moneta za słowo: bułgarskie bajki i legendy ludowe, wybór i wstęp Georgi Minczew, przeł. Agata Kawecka et al., il. Małgorzata Beata Piechowiak, Łódź: Wydawnictwo Uniwersytetu Łódzkiego, 2006, ss. 314.

Słowa kluczowe: literatura bułgarska; bułgarska kultura ludowa; bajki bułgarskie; baśnie ludowe; legendy; podania.

Treść: Zawiera artykuł: Bułgarskie bajki i legendy ludowe - między uniwersalną a regionalną wizją świata (s. 7-32). Część I. Bajki magiczne. Część II. Bajki zwierzęce. Część III. Bajki nowelistyczne i anegdoty. Część IV. Legendy i podania ludowe. Wykaz skrótów, bibliografia, komentarze, słownik istot i pojęć mitycznych oraz bajkowych, słowniczek wyrazów obcych. 


\section{7}

\section{Monografie:}

93. Mleczko Joanna, Bułgarskie pieśni łazarskie: próba systematyki pieśni obrzędowych, Katowice: Wydawnictwo UŚ, 2007, ss. 144.

Słowa kluczowe: bułgarska pieśń ludowa; pieśni łazarskie; „łazaruwane”; folklor bułgarski.

Treść: Monografia stanowi próbę systematyki bułgarskich pieśni łazarskich oraz odpowiedzi na pytanie o ich miejsce i rolę w obrzędzie, którego realizacji towarzyszą (wiosenny obrzęd panieński „łazaruwanie”). Systematykę przeprowadzono w oparciu o najliczniejszą spośród grup pieśni, a tym samym najbardziej reprezentatywną i najważniejszą grupę pieśni, które uczestniczące w obrzędzie dziewczęta w wieku przedmałżeńskim wykonują w obejściach odwiedzanych domostw lub w specjalnej przestrzeni publicznej.

94. Walczak-Mikołajczakowa Mariola, Chrześcijańska Bułgaria, Poznań: Drukarnia i Księgarnia Świętego Wojciecha, 2007, ss. 27 [5].

Słowa kluczowe: wyznania w Bułgarii; chrześcijaństwo; car Borys; franciszkanie w Bułgarii; misje chrześcijańskie w Bułgarii.

Treść: Broszura Księgarni Świętego Wojciecha z serii Chrześcijańska Europa poświęcona dziejom obrządku zachodniego w Bułgarii - począwszy od IX w. - i kontaktom Michała-Borysa z Rzymem, przez misję franciszkanów z Bośni w XIV w., po współczesność, kiedy to - jak pisze autorka - w Bułgarii mieszka 60-tysięczna grupa ludności wyznania rzymskokatolickiego.

\section{Opracowania źródłowe:}

95. Historia Bułgarii 1870-1915: materiały źródłowe z komentarzami. T.2, Kwestia macedońska, oprac. Jarosław Rubacha Jarosław, Andrzej Malinowski, Warszawa: „Neriton”, 2007, ss. 149.

Słowa kluczowe: polityka Bułgarii; historia Bułgarii; kwestia macedońska; Półwysep Bałkański.

Treść: Drugi tom serii Historia Bułgarii 1870-1915 zawiera materiały źródłowe ukazujące rangę tzw. kwestii macedońskiej w polityce bułgarskiej, jak również stosunek Bułgarów macedońskich do wydarzeń rozgrywających się na Półwyspie Bałkańskim. Składa się na niego ponad 40 dokumentów przetłumaczonych z języka bułgarskiego, angielskiego, rosyjskiego i francuskiego opatrzonych komentarzami, prezentującymi je na tle aktualnej sytuacji politycznej w Macedonii i na Bałkanach. 


\section{8}

\section{Monografie:}

96. Jóźwiak Wojciech, Piśmiennictwo polskiej misji unickiej na terenie Bułgarii $w$ drugiej połowie XIX wieku, Kraków: „Alleluja” Wydawnictwo Zmartwychwstańców, 2008, ss. 207.

Słowa kluczowe: Zmartwychwstańcy; kościoły prawosławne w Bułgarii; misje katolickie w Bułgarii; unici; literatura polska.

Treść: Autor opisuje historię, działalność i piśmiennictwo polskiej misji unickiej Zgromadzenia Zmartwychwstania Pańskiego w latach 1860-1914. Opisywany okres był dla Bułgarii czasem eksplozji świadomości narodowej, literatury odrodzeniowej oraz początkiem bułgarskiej państwowości. W tym szerokim kontekście historycznym, kulturowym i wyznaniowym autor analizuje zagadnienia związane z działaniami polskich misjonarzy zmierzające do unii bułgarskiej Cerkwi prawosławnej z Kościołem rzymskim. Wstęp: Rzym-Bułgaria, historia kontaktów. Rozdział I: Bułgarskie dążenia pro- i antyunickie. Rozdział II: Dorobek literacki członków polskiej misji unickiej na terenie Bułgarii.

97. Nowosad Andrzej, Władza i media w Bułgarii, Kraków: Wydawnictwo UJ, 2008, ss. 518.

Słowa kluczowe: media w Bułgarii; prasa bułgarska; polityka Bułgarii; konstytucja $1878 \mathrm{r}$.

Treść: Praca poświęcona kształtowaniu się systemu medialnego Bułgarii na tle wydarzeń politycznych i społecznych od I połowy XIX do początku XXI wieku. Szczegółowo omówiono w niej: powstanie i rozwój pierwszej prasy bułgarskiej w XIX wieku, kształtowanie sfery medialnej Księstwa Bułgarii w szerokim kontekście doktryny konstytucyjnej z 1878 roku, prasę okresu carstwa Bułgarii, uwarunkowania polityczne przy kształtowaniu sfery medialnej Bułgarii w okresie wprowadzania demokracji w tym kraju i tuż przed przystąpieniem Bułgarii do Unii Europejskiej. Książkę zamyka panorama krajowych, regionalnych i etnicznych mediów w Bułgarii.

98. Skowronek Małgorzata, „Świat cały ma Cię za obroncę”: Michał Archanioł w kulturze Słowian prawosławnych na Bałkanach, Łódź: Wydawnictwo UŁ, 2008, ss. 240.

Słowa kluczowe: Michał Archanioł; kult świętych; prawosławie; Słowianie Południowi; literatury słowiańskie; literatura prawosławna.

Treść: Bazująca na rękopisach oraz niepublikowanych materiałach praca jest poświęcona obrazowi Michała Archanioła w kulturze prawosławnych Słowian na Bałkanach. Michał 
Archanioł - jako jeden z najpopularniejszych świętych i najsłynniejszy z aniołów - od początków chrześcijaństwa otaczany jest wyjątkową czcią. Na ten stan składa się cały szereg czynników, do których należą m.in. wyobrażenia tradycji judaistycznej, rozwój kultu w łonie samego chrześcijaństwa, związane z imieniem Świętego dziedzictwo literatury i sztuk pięknych, a także nakładanie się na stare kulty pogańskie pierwiastków wiary i religijności chrześcijańskiej oraz wierzeń ludowych. Wizerunek św. Michała powstały w kulturze prawosławnych Słowian bałkańskich jest z pewnością niejednowymiarowy, lecz jednocześnie synkretyczny, co decyduje o jego specyfice i wyjątkowości.

\section{Prace zbiorowe:}

99. Nowe spojrzenie na kulturę bułgarską: materiały z drugiej międzynarodowej konferencji studenckiej, Poznań 11-12 grudnia 2003 roku, red. Diana Ivanowa, Tadeusz Lewaszkiewicz, Natalia Reczek, Poznań: Katedra Filologii Słowiańskiej UAM, 2008, ss. 168.

Słowa kluczowe: folklor bułgarski; język bułgarski; literatura bułgarska; przekłady bułgarskie.

Treść: M. Farion: Mit Wasyla Lewskiego w kulturze bułgarskiej; N. Cybart: Nieznana historia Bułgarii pióra krakowskiego jezuity Józefa Hołubowicza; И. Караденизова: Функции на огъня и огнище у българите; K. Lelewska: Функционална характеристика на обредите Пеперуда и Герман в България и Сърбия; E. Drzewiecka, E. Majuk: Bułgarski strój kobiecy w kulturze ludu i narodu (z elementami porównania ze strojem polskim); M. Wojtczak: Swięty Klemens Ochrydzki w poodrodzeniowym i międzywojennym okresie literatury bułgarskiej; K. Krzeszewska: Bajka „Uczeń diabła” w Polsce i w Bułgarii; M. Malicka: Twórczość Georgiego Gospodinowa wświetle zjawiska ,wartościowego bestsellera”; M. Pytlak: Istnienie fragmentaryczne. O istnieniu literatury bułgarskiej w Polsce po 1989 roku. Szkic; Т. Тодорова: Димитьр Мутев (1818-1864) - основател на списание „Български книжици; Ł. Mysielski: Bułgarska kronika apokryficzna - między apokalipsa a historia.

\section{9}

\section{Monografie:}

100.Solak Elżbieta, Znaki szczególne. Językowe i wokótjęzykowe problemy butgarskiego Odrodzenia, Kraków: Wydawnictwo UJ, 2009, ss. 355 [1].

Słowa kluczowe: język bułgarski; kultura bułgarska; piśmiennictwo bułgarskie; bułgarskie odrodzenie narodowe.

Treść: Publikacja traktuje o tkwiących w XIX wieku źródłach bułgarskiego kodu patriotycznego, stanowiących o stosunku współczesnych Bułgarów do wielkich naro- 
dowych narracji. Autorka porusza kwestię aktualizacji starych mitów wspólnotowych, poszukiwania mitów nowych, jak również słów-kluczy oraz utrwalonych w języku i tekstach kultury stereotypach wyznaczających granice przewartościowań.

101. Walczak-Mikołajczakowa Mariola, Bułgarski Ezop, Poznań: Wydawnictwo UAM, 2009, ss. 180 [1].

Słowa kluczowe: Ezop; przekłady bułgarskie; język bułgarski; bułgarskie odrodzenie narodowe; bajki.

Treść: Praca podejmuje zagadnienie nowobułgarskich XIX-wiecznych przekładów bajek Ezopa. Przekłady te są ważne nie tylko dlatego, że za ich sprawą pojawił się nowy bohater literatury, ale również z powodu popularyzowania za ich pośrednictwem określonej postawy językowej pisarzy tego okresu. Bajki były w XIX-wiecznej Bułgarii rodzajem oręża używanego w walce o kształt nowej bułgarszczyzny literackiej, a działalność przekładowa przez ponad połowę XIX wieku czynnikiem, który odgrywał znaczącą rolę w kształtowaniu bułgarskiego standardu językowego.

\section{Prace zbiorowe:}

102. Biblia Slavorum Apocryphorum. Novum Testamentum. Materiały z Międzynarodowej Konferencji Naukowej (Łódź, 15-17 maja 2009), red. Georgi Minczew, Ivan Petrow, Małgorzata Skowronek, Łódź: Uniwersytet Łódzki, Wydawnictwo Gabriela, 2009, ss. 317.

Słowa kluczowe: Biblia; Nowy Testament; Słowianie Południowi; apokryfy.

Treść: М. В. Рождественская: Канон и апокриф как литератуный источник: воскресение Лазаря, воскресение Христово, успение Богородицы; М. Kuсzyńska: „Aby nikt z prawosławnych i pobożnych chrześcijan tych ksiag w cerkwiach ani domach nie trzymat, nie czytał, nie kupował" - albo w poszukiwaniu kanonu; E. Siatkowska: Judasz potępiony, Judasz rehabilitowany w świetle wybranej literatury apokryficznej; E. Woźniak: Kanoniczny i apokryficzny obraz Piłata (na materiale staropolskich narracji biblijno-apokryficznych; M. Skowronek: Legenda o królu Abgarze w wybranych słowiańskich tekstach użytku liturgicznego; D. Češmedžiev: Bułgarska tradycja państwowa w apokryfach: car Piotr w bułgarskiej kronice apokryficznej; E. Bakalova: Principles of visualization of the pseudo-canonical texts in the art of the Byzantine commonwealth; E. Drzewiecka: Między forma a treścią. Motywy pseudokanoniczne w ikonografi święta zaśnięcia Bogurodzicy w serbskim malarstwie ściennym z XIV w.; $\mathrm{K}$. Wrocławski: O sposobie przyjmowania inspiracji Ewangeliq (na podstawie macedońskiej legendy „Bogurodzica i żaba”; Ł. Mysielski: „Opowieść o drzewie krzyżowym” Prezbitera Jeremiasza a tradycja oralna (na przykładzie bułgarskich i serbskich legend apokryficznych. 
103. Napisać kobiete.... Dyskusje bułgarsko-polskie w latach transformacji, red., wybór Magda Karabełowa, Anna Nasiłowska; przeł. Hanna Karpińska et al.; Sofia: „Bojan Penew”, 2009, ss. 239.

Słowa kluczowe: literatura bułgarska; kobieta; gender studies; płeć kulturowa; literatura polska.

Treść: tom publikacji badaczy polskich i bułgarskich wydany w pol. i bułg. wersji językowej; streszczenia ang. Artykuły: A. Nasiłowska: Kobiety, dyskurs, literatura $w$ Polsce i w Bułgarii; R. Bożankowa: Anna in your headJ lub o pisarstwie kobiecym $w$ Internecie; I. Iwasiów: Pisarstwo kobiet w perspektywie zmian pokoleniowych i cywilizacyjnych; E. Dimitrowa: $W$ dwugłosie jednej myśli; P. Antow: Pani G. - posiadana i posiadajaca - aporie; A. Waczewa: Kobiety: przestrzeń intymna a uprawnienia społeczne; E. Trajkowa: Pisarstwo kobiece - wyzwania i ograniczenia. Obserwacje na materiale powieści Marii Stankowej; E. Graczyk: Spotkanie po latach; G. Simeonowa-Konach: Kobieta-polityk, media i transformacja; R. Kolewa: Teodora Dimowa - między tajemnica pisarstwa a bluźnierstwem.

\section{Opracowania źródłowe:}

104. Historia Bułgarii 1870-1915: materiały źródłowe z komentarzami. T. 3, Polityka wewnętrzna, oprac. Jarosław Rubacha, Andrzej Malinowski, Warszawa: „Neriton”, 2009, ss. 172.

Słowa kluczowe: polityka Bułgarii; historia Bułgarii; Konstytucja Tarnowska; manifesty polityczne; ustawy i rozporządzenia.

Treść: Tom trzeci serii Historia Bułgarii 1870-1915 prezentuje najważniejsze akty prawne i dokumenty związane z nowożytną historią Bułgarii. Autorzy prezentują materiały źródłowe odnoszące się do polityki wewnętrznej w podziale na poszczególne płaszczyzny życia społecznego - od Konstytucji Tarnowskiej i Statutu Organicznego Rumelii Wschodniej, przez odezwy i manifesty władców bułgarskich, po ustawy i rozporządzenia regulujące politykę kulturalno-oświatową. Poszczególne grupy dokumentów opatrzono szczegółowymi komentarzami, odnoszącymi źródła do ówczesnej sytuacji w Bułgarii.

\section{0}

\section{Podręczniki:}

105. Czekalski Tadeusz, Bułgaria, Warszawa: „Trio”, 2010, ss. 374 [2].

Słowa kluczowe: historia Bułgarii; polityka Bułgarii; społeczeństwo bułgarskie; kultura bułgarska. 
Treść: Pierwsza w Polsce próba całościowego ujęcia dziejów Bułgarii w dwudziestym stuleciu. We wprowadzeniu znalazł się zarys dziejów Bułgarów i Bułgarii od czasu ich pojawienia się na mapie Europy do odrodzenia państwowości i uzyskania pełnej suwerenności w roku 1908. Zasadnicze część pracy obejmuje okres od proklamowania Carstwa Bułgarii (Królestwa Bułgarii) do przyjęcia tego kraju do Unii Europejskiej w roku 2007. Oprócz klasycznego wykładu historii politycznej, znaczną część pracy zajmują kwestie przemian demograficzno-społecznych, a także najciekawszych zjawisk w kulturze bułgarskiej dwudziestego stulecia. Szczególne rozbudowane zostały wątki mające istotne znaczenie w dyskusji nad kondycją współczesnego społeczeństwa bułgarskiego, w tym próba naszkicowania ekonomicznych, a także obyczajowych konsekwencji okresu rządów Todora Żiwkowa.

\section{Monografie:}

106. Żejmo Bożena, Ponad stan: motywy transgresyjne w twórczości Jordana Jowkowa, Toruń: Wydawnictwo Naukowe UMK, 2010, ss. 335.

Słowa kluczowe: Jordan Jowkow; antropologia filozoficzna; proza bułgarska, transgresja; melancholia.

Treść: Praca podejmuje zagadnienie motywów transgresyjnych w twórczości bułgarskiego prozaika Jordana Jowkowa w ujęciu antropologicznym. W obszarze zainteresowania autorski znajdują się m.in. motywy śmierci, choroby, wojny, figury pięknych grzesznic, jak również upostaciowienia homo transgressivus oraz homo melancholicus.

\section{Prace zbiorowe:}

107. Uczniowie Apostołów Słowian. Siedmiu Świętych Mężów, oprac. Małgorzata Skowronek, Georgi Minczew, Kraków: „Collegium Columbinum”, 2010, ss. 216.

Słowa kluczowe: Klemens z Ochrydy; Naum z Ochrydy; święci i błogosławieni; Słowianie południowi; literatura chrześcijańska.

Treść: tom wydany w roku Jubileuszu 1100 lat od Zaśnięcia Świętego Nauma Cudotwórcy Ochrydzkiego. Artykuły: M. Skowronek: Zamiast wstępu; S. Barlieva, D. Češmedžijev: Uczniowie Apostołów Słowian. Siedmiu Świętych Mężów w greckiej i słowiańskiej tradycji literackiej; E. Bakalova: Siedmiu Świętych Mężów w sztukach pięknych; G. Minczew: Pamięć o Siedmiu Świętych Mężach w legendach ludowych i podaniach. HAGIOGRAFIA (m.in. Anonim, Pierwszy słowiański żywot Świętego Nauma, przeł. M. Skowronek; Dymitr Chomatian: Żywot krótki Świętego Klemensa Ochrydzkiego (Legenda ochrydzka), przeł. A. Maciejewska; HYMNOGRAFIA (m.in. Anonim z Ochrydy: Słowiańskie nabożeństwo ku czci Świętego Klemensa, przeł. A. Naumow; Biskup Parteniusz: Sło- 
wiańskie nabożeństwo ku czci Siedmiu Świętych Mężów, przeł. I. Petrov); LEGENDY LUDOWE I MEMORATY Z OKOLIC OCHRYDY ( m.in. Święty Klemens $i$ wdowa, przeł. M. Skowronek; Car Samuel i Święty Klemens, przeł. M. Skowronek; Święty Naum i smok, przeł. M. Skowronek; Jak Turcy czcza Świętego Nauma, przeł. M. Skowronek)

\section{1}

\section{Słowniki i bibliografie:}

108. Sotirow Petyr, Mostowska Mariola, Mokrzycka Agata, Bułgarsko-polski słownik leksyki potocznej. T. 1 (A-J), Lublin: Wydawnictwo UMCS, 2011, ss. 280.

Słowa kluczowe: słowniki bułgarsko-polskie; język bułgarski; język polski; język potoczny; słownictwo.

\section{Podręczniki:}

109. Szwat-Gyłybowa Grażyna, Drzewiecka Ewelina et al., Leksykon tradycji bułgarskiej, red. nauk. Grażyna Szwat-Gyłybowa, konsult. naukowa Aleksander Naumow, Warszawa: Slawistyczny Ośrodek Wydawniczy, 2011, ss. 376.

Słowa kluczowe: historia Bułgarii; kultura Bułgarii; folklor bułgarski; literatura bułgarska.

Treść: Leksykon prezentuje kluczowe dla bułgarskiej wielkiej narracji narodowej miejsca pamięci zbiorowej. Jako cezurę wyznaczającą granice definiowania haseł obrano rok 1913. W pierwszej części haseł umieszczono informacje faktograficzne, encyklopedyczne minimum wiedzy na dany temat; $w$ drugiej części znalazła się refleksja nad różnymi formami adaptacji danego faktu, dzieła, zdarzenia, postaci czy zjawiska do zmieniających się w procesie historycznym potrzeb zbiorowości, ale także do potrzeb ośrodków władzy aspirujących do kontroli nad świadomością zbiorową. Pod każdym ze 140 haseł znajdują się wskazówki bibliograficzne. Dzieło zamyka bibliografia wybranych opracowań naukowych (bułgarskich i polskich) z zakresu podejmowanej problematyki.

\section{Monografie:}

110. Borowiak Patryk, Płowdiw w nazwach: historia i współczesność w toponimii zapisane, Toruń: „Adam Marszałek”, 2011, ss. 220.

Słowa kluczowe: miasta bułgarskie; nazwy miejscowe bułgarskie; onomastyka; Płowdiw; bułgarskie odrodzenie narodowe; historia Bułgarii. 
Treść: Monografia przedstawia nazewnictwo miejskie oraz jego rozwój na przykładzie bułgarskiego miasta Płowdiw. Książka językoznawcza, ale w dużej mierze interdyscyplinarna, dająca czytelnikowi rozległą wiedzę na temat historii miasta, stosunków panujących w nim na przestrzeni wieków, polityki zmieniających się władz odrodzonej w XIX wieku Bułgarii.

\section{Gołek-Sepetliewa Dorota, Formuły absurdu w twórczości poetyckiej Kon- stantina Pawłowa, Kraków: „Lexis”, 2011, ss. 142.}

Słowa kluczowe: Konstantin Pawłow; poezja bułgarska; BRL; dysydenci w Bułgarii; polityka w Bułgarii; absurd w literaturze bułgarskiej.

Treść: Monografia literaturoznawcza, próba całościowej prezentacji twórczości poetyckiej Konstantina Pawłowa (1933-2008), bułgarskiego poety i dysydenta, którego twórczość była w Bułgarii objęta zakazem do lat osiemdziesiątych XX wieku. Autorka skupia się na kategorii absurdu, dla której rozumienia kluczowa staje się filozofia egzystencjalna. Wywód przebiega w oparciu o analizę kategorii czasu, przestrzeni, konstrukcji podmiotu lirycznego.

112. Moroz-Grzelak Lilla, Bracia Słowianie. Wizje wspólnoty a rzeczywistość, Warszawa: Slawistyczny Ośrodek Wydawniczy, 2011, ss. 333.

Słowa kluczowe: panslawizm; „bracia Słowianie”; historiografia Słowian; narody słowiańskie; literatury słowiańskie.

Treść: Studium z zakresu historii idei poświęcone jest etnicznym związkom wspólnotowym w świecie słowiańskim. W oparciu o bogate źródła z piśmiennictwa pięciu narodów słowiańskich (polskiego, chorwackiego, serbskiego, bułgarskiego i macedońskiego) omówiono w nim wizje tworzonej w XIX wieku wspólnoty etnicznej, którą wyrażano za pomocą zwrotu „bracia Słowianie”. Badany materiał, jaki stanowią publicystyka, dokumenty polityczne, druki ulotne i literatura piękna, pozwolił na ujawnienie mitologizacji Słowiańszczyzny i mechanizmów kreowania jej historii. W książce nie ograniczono się tylko do okresu, gdy frekwencja występowania wyrażenia była największa i kiedy w obliczu powstawania państw narodowych postępowała dewaluacja wizji wspólnotowych. Niezwykle ważne jest ukazanie kontekstu wcześniejszych odwołań do związków słowiańskich, powrotu wyobrażeń o jedności etnicznej w obliczu zagrożeń w XX wieku oraz przedstawienie współczesnych projektów i działań opierających się na przeświadczeniu o istnieniu więzi krwi, które łączą narody słowiańskie.

\section{Prace zbiorowe:}

113. Bałkański folklor jako kod interkulturowy, Tom I, red. Joanna Rękas, Poznań: Wydawnictwo Naukowe Uniwersytetu im. Adama Mickiewicza, 2011, ss. 596.

Słowa kluczowe: folklor bałkański; Słowianie Południowi; literatury bałkańskie. 
Treść: Tom otwierający serię prac zbiorowych, których wspólnym mianownikiem jest potrzeba odkrywania, dekodowania i dzielenia się wiedzą o tradycyjnym i współczesnym folklorze narodów bałkańskich. Przyjęta definicja folkloru jest szeroka, łączy dorobek badawczy zarówno filologów literaturoznawców i językoznawców, jak i etnologów, etnografów, antropologów, kulturoznawców i religioznawców. Założeniem redakcyjnym jest prezentacja oraz, co ważniejsze, konfrontacja wyników współczesnych eksploracji naukowych i popularnonaukowych zorientowanych na problemy terytorialnych, narodowych i wspólnotowych wyznaczników i form bałkańskiego folkloru. Artykuły: K. Wrocławski, Narodowy i ponadnarodowy wymiar folkloru słowiańskiego; К. Петровска-Кузманова, Истражувачката историја на народната драмаво балканската фолклористика; Б. Сувајџић, Хајдучки фолклор као балкански културни код (поетика жанра); С. Дживтерева, Обеществяване на хронотопа в две обредни песни; J. Mleczko, Słowo a obrzęd (na przykładzie bułgarskiego „łazaruwane”); Б. Стојковски, Византија, Запад и Јужни Словени - интеркултурна прожимана на примеру музике; M. Walczak-Mikołajczakowa, Jak wyrazić ból i żal? Współczesne bułgarskie wspomnienia o zmartych; N. Długosz, Językowo-kulturowy obraz demona „karakondżol” w bułgarskiej tradycji ludowej; R. Bońkowski, Nazwy pierwszego miesiaca roku oźródłosłowie prasłowiańskim we współczesnych językach słowiańskich; L. Miodyński, Idiomatyka folklorystyczna w projekcie wyobraźni poezji macedońskiej; W. Jóźwiak, Iwajło - bułgarski bohater ludowy „nowych czasów”; B. Hoffmann, Rola folkloru w tworzeniu współczesnej rzeczywistości społecznej: między perspektywą lokalna a globalną. Rozważania na podstawie wybranych przykładów współczesnej muzyki bałkańskiej.

114. Poznać Bałkany: historia, polityka, kultura, red. Katarzyna Taczyńska, Szymon Sochacki, Miloš Zečević, Toruń: Interdyscyplinarne Koło Naukowe Doktorantów UMK, 2011, ss. 321.

Słowa kluczowe: Bałkany; Słowianie Południowi; literatury bałkańskie; języki bałkańskie; bałkanizm; orientalizm.

Treść: Tom wydany z inicjatywy Interdyscyplinarnego Koła Naukowego Doktorantów UMK, niemal w całości poświęcony zagadnieniom dotyczącym krajów byłej Jugosławii. Referat dotyczący Bałkanów: J. Wygnańska: Zjawisko bałkanizmu a dyskurs orientalny.

\section{Opracowania źródłowe:}

115. Stępnik Krzysztof, Wojny bałkańskie lat 1912-1913: korespondencje wojenne i komentarze polityczne, Lublin: Wydawnictwo UMCS, 2011, ss. 262.

Słowa kluczowe: korespondencja wojenna; wojny bałkańskie; publicystyka polska.

Treść: Autor wyboru sięgnął do korespondencji wojennych ( m.in. Filipa Kupczyńskiego, Mieczysława Jełowickiego, Tadeusza Micińskiego, Józefa Lipkowskiego, 
Kazimierza Grusa), komentarzy (m.in. Feliksa Konecznego, Zdzisława Maryckiego). Teksty zamieszczone $\mathrm{w}$ tomie po blisko stu latach od ich publikacji nic nie straciły na aktualności. Stanowią one zapis naocznych świadków wojen bałkańskich, ale też postaci zaangażowanych w temat i na różne sposoby próbujących przybliżyć ją Polakom.

\section{2}

\section{Monografie:}

116. Lubańska Magdalena, Synkretyzm a podziały religijne w bułgarskich Rodopach, Warszawa, Wydawnictwa UW, 2012, ss. 340.

Słowa kluczowe: islam; prawosławie; muzułmanie; wyznania w Bułgarii; Rodopy Zachodnie; Macedonia; Bośnia.

Treść: Przedmiotem pracy jest analiza wierzeń i praktyk religijnych muzułmańsko-prawosławnych społeczności lokalnych Rodopów Zachodnich, badanych pod kątem stosunku tych społeczności do sąsiadów-innowierców. Prezentowane studium dotyczy społeczności muzułmańsko-prawosławnych z Rodopów Zachodnich, które łączy podobieństwo losów historycznych z mieszkańcami terenów mieszanych pod względem konfesyjnym w Macedonii czy Bośni.

\section{Rubacha Jarosław, Bułgaria na przełomie XIX i XX wieku. Bułgarskie metamorfozy w publikacjach „Świata Słowiańskiego” (1905-1914), Olsztyn: Wydawnictwo UWM, 2012, ss. 586.}

Słowa kluczowe: historia Bułgarii; polityka Bułgarii; „Świat Słowiański”; Słowianie; czasopisma polskie; stosunki polsko-bułgarskie.

Treść: Książka przynosi nowe i zarazem wielopłaszczyznowe spojrzenie na dzieje Bułgarii na przełomie XIX i XX wieku. Okres ten charakteryzował się nie tylko dynamicznie zachodzącymi w Polsce procesami natury politycznej i społecznej, ale także znaczącym przyśpieszeniem w zakresie budowy trwałych podstaw gospodarki bułgarskiej i rozwojem kultury. Był to także czas kontrowersyjnych decyzji podejmowanych przez bułgarskich monarchów i kolejne gabinety, do dziś budzących spory i dyskusje wśród naukowców. Autor analizuje tematykę bułgarską w wychodzącym pod austriackim zaborem w latach 1905-1914 miesięczniku „Świat Słowiański”, w którym wybitni polscy historycy, filozofowie, politycy próbowali wpływać na rozszerzającą się idee słowiańskiej tożsamości i wspólnoty. Pismo grupujące największe ówczesne nazwiska przeciwstawiało się panslawizmowi rosyjskiemu, który Słowianom starała się narzucić dyplomacja rosyjska.

118. Siedlecka Sylwia, Poganki i intelektualistki. Bohaterki Błagi Dimitrowej, Warszawa: Slawistyczny Ośrodek Wydawniczy, 2012, ss. 222. 
Słowa kluczowe: literatura bułgarska; elity bułgarskie; komunizm; BRL; Błaga Dimitrowa.

Treść: Proza i dramaty bułgarskiej pisarki, poetki i intelektualistki Błagi Dimitrowej są cennym, bo rzadkim w bułgarskiej literaturze, zapisem poszukiwań bułgarskich elit drugiej połowy XX wieku. W książce są one analizowane na tle długiej tradycji bułgarskich narracji na temat pojęć: narodu, dziedzictwa historycznego, modernizacji, kobiecości oraz stosunku do Innego. Tytułowe poganki i intelektualistki stanowią filary ideowego projektu Błagi Dimitrowej, który jest odpowiedzią na wzorce wywodzące się zarówno z tradycji filozoficznej Zachodu, jak i z lokalnego, bałkańskiego archiwum form. Wątki religijne splatają się w nim z politycznymi, inspiracje bułgarskim folklorem ze spuścizną francuskiego Oświecenia, a fascynacja figurą Fausta z uwzniośleniem bałkańskiego Barbarogeniusza.

\section{Woźnica Rafał, Bułgarska polityka wewnętrzna a proces integracji z Unia} Europejską, Kraków: „Księgarnia Akademicka”, 2012, ss. 290 [6].

Słowa kluczowe: Bułgaria a Unia Europejska; polityka wewnętrzna Bułgarii; demokracja; społeczeństwo bułgarskie.

Treść: Praca przedstawia procesy zachodzące w bułgarskiej polityce wewnętrznej, które wpływały na integrację Bułgarii z Unią Europejską. Celem publikacji jest nie tylko zestawienie faktów politycznych, gospodarczych, społecznych itd., determinujących integrację traktowaną jako etap na drodze do formalnego członkostwa w Unii Europejskiej uzyskanego przez Bułgarię 1 stycznia 2007 roku, ale także prezentacja najważniejszych problemów stojących przed tym krajem: demokratyzacji, konsolidacji nowego ustroju oraz integracji $z$ UE. Jednym $z$ istotnych zadań pracy było ukazanie pozytywnego znaczenia Unii Europejskiej, która zmuszała nowych kandydatów (w tym przypadku Bułgarię) do przeprowadzenia szeregu reform w zakresie polityki wewnętrznej.

\section{Prace zbiorowe:}

120. Chrześcijański schód i Zachód: formy dialogu, wzory kultury, kody pamięci, red. nauk. Izabela Lis-Wielgosz, Wojciech Jóźwiak, Poznań: IFS UAM, 2012, ss. 562.

Słowa kluczowe: katolicyzm; prawosławie, komunikacja międzykulturowa; unici bułgarscy.

Treść: Pierwszy tom z serii Przestrzenie Kultury, poświęcony problematyce wzajemnych relacji, interakcji słowiańskiego Wschodu i Zachodu. Impulsem do stworzenia tomu była 150. rocznica podpisania przez Bułgarów unii z Kościołem rzymskokatolickim. 
Artykuły: W. Jóźwiak: Литературно-просветителски аспект на дейността на униатската мисия на отиите възкресенци в Адрианопол през втората половина на ХІХ век; G. Simeonova-Konach: „Pascha Bułgarska”. Unia i jej konteksty konstantynopolitańskie w badaniach prof. Tonczo Żeczewa; L. Jaworska: Unici bułgarscy - społeczność na granicy kultur i religii. Obraz ukazany w „Kalendarzach św. św. Cyryla i Metodego; A. Naumow: Ksenofobia i nieufność jako mechanizmy współżycia chrześcijan; J. Stradomski: Antyłacińskie pisma polemiczne w rękopisach cerkiewnosłowiańskich w Polsce; M. Walczak-Mikołajczakowa: Dialekt w służbie religii (na przykładzie bajek bułgarskich katolików); J. Pietrzak-Thebault: Biedny Francuz patrzy na Prawosławie - fascynacje, stereotypy, iluzje; B. Żejmo: Postać Imitatio Christi w literaturze bułgarskiej i rosyjskiej; E. Drzewiecka: „Любовта е върховна омраза". Transformacje pojęć chrześcijańskich w powieści Nikołaja Rajnowa: Meжdy пустинята и живота"; P. Dziadul: Topika bizantyńsko-słowiańskiego piśmiennictwa apokaliptycznego jako komponent chrześcijańskiej wizji „czasów ostatecznych”; E. Prałat: Granice w jedności. Kulturowa unifikacja Półwyspu Bałkańskiego na podstawie iluminowanych dekoracji wybranych mszałów średniowiecznych; L. Moroz-Grzelak: Ekumena a obcość w pismach Pawła Smolikowskiego. Misje katolickie w dziewiętnastowiecznej Bułgarii; T. Lewaszkiewicz, Problem przekładów Biblii na języki ludowe w świecie słowiańskim (na tle europejskim).

121. Poznać Bałkany: historia, polityka, kultura, języki. 3, red. Wiara Małdżiewa, Katarzyna Taczyńska, Toruń: IFS UMK, 2012, ss. 395.

Słowa kluczowe: Bałkany; Słowianie Południowi; literatury bałkańskie; języki bałkańskie; Bułgaria; Macedonia.

Treść: Trzecia część toruńskiego cyklu bałkanistycznego. Artykuły: . Fleischerowicz: Writing Macedonian Identity. Between Historical and Linguistic Sciences, Educational Processes and Anthropological Thinking; B. Żejmo: "Светите безумии" в руската и българската литература.

122. Poznać Bałkany: historia, polityka, kultura, języki. 4, red. Katarzyna Taczyńska, Aleksandra Twardowska, Toruń: IFS UMK, 2012, ss. 555.

Słowa kluczowe: Bałkany; Słowianie Południowi; literatury bałkańskie; języki bałkańskie; historia Bałkanów.

Treść: W. Sajkowski: Barbarzyńcy czy „szlachetni dzikusi” - obraz Słowian Południowych $w$ Wielkiej Brytanii czasów oświecenia; K. Miłoszewska: Jak zbudowany jest „Koncert na zdanie", czyli o synkretyzmie sztuk w prozie Emilii Dworjanowej; D. Gapska: Aniołowie w południowosłowiańskich tekstach hagiograficznych i apokryficznych; J. Duda: Virgjinesha $i$ ich rola $w$ społeczeństwie na Bałkanach; M. Bednarek: Kult bliźniaczy 
w folklorze bułgarskim. Święci bliźniacy; K. Usakiewicz: Aleksander Wielki - od postaci historycznej do bohatera kulturowego.

123. Topografia tożsamości, Tom I, red. Bogusław Zieliński, Poznań: Wydawnictwo UAM, 2012, ss. 195.

Słowa kluczowe: literatury europejskie; narody europejskie; geopolityka europejska; kultura bułgarska; język bułgarski.

Treść: Zbiór studiów o charakterze interdyscyplinarnym. Autorzy rozpatrują geokulturowe aspekty kultur narodowych w szerokim spektrum problemowym, czerpiąc inspiracje z różnych nurtów współczesnej humanistyki - głównie z zakresu teorii oraz historii literatury - ze szczególnym uwzględnieniem perspektywy interkulturowej i studiów komparatystycznych, kulturoznawstwa i teorii postkolonialnej. Wśród inspiracji metodologicznych znajdą się stanowiska, które interpretację faktów literackich wiążą z heurystyką narodowego losu, historii, narodowej filozofii, a także różnorodne stanowiska w obrębie krytyki postkolonialnej. Prace zawarte w tomie sytuują się w dwóch zakresach tematycznych: Miasta ze słów oraz Miejsca pamięci, pamięć przestrzeni. Artykuły o Bułgarii i Macedonii: Г. Симеонова-Конах: Градъm или градината с манекените; L. Miodyński: Geometria nieobecności. Szlaki wykorzenienia w macedońskim obrazie kulturowym.

124. Topografia tożsamości, Tom II, red. Agata Firlej, Wojciech Jóźwiak, Poznań: Wydawnictwo UAM, 2012, ss. 360.

Słowa kluczowe: literatury europejskie; narody europejskie; geopolityka europejska; kultura bułgarska; język bułgarski.

Treść: Zbiór studiów o charakterze interdyscyplinarnym. Autorzy rozpatrują geokulturowe aspekty kultur narodowych w szerokim spektrum problemowym, czerpiąc inspiracje z różnych nurtów współczesnej humanistyki, głównie z zakresu teorii oraz historii literatury, ze szczególnym uwzględnieniem perspektywy interkulturowej i studiów komparatystycznych, kulturoznawstwa i teorii postkolonialnej. Wśród inspiracji metodologicznych znajdą się stanowiska, które interpretację faktów literackich wiążą z heurystyką narodowego losu, historii, narodowej filozofii, a także różnorodne stanowiska w obrębie krytyki postkolonialnej. Teksty ujęte są w części: Przestrzenne kody tożsamości kulturowej, Język, przestrzeń, tożsamość oraz Szlaki kulturowe

Artykuły bułgarystyczne: G. Szwat-Gyłybowa: (Nie)konwencjonalny trakt outsidera. O dylematach bułgarskich intelektualistów; W. Jóźwiak: Oczyszczajaca wyprawa na Wschód w XX-wiecznej bułgarskiej prozie historycznej; M. Walczak-Mikołajczakowa: Język trwałym wykładnikiem kultury Bułgarów banackich (na przykładzie najnowszego wydania katechizmu); M. Slavova, D. Michułka: Podróż jako przejście inicjacyjne $w$ bułgarskiej i polskiej prozie dziecięcej. 


\section{Indeks}

\section{Łaciński}

A

Ajdačić, D. 499

Aleksandrowa-Gonczewa, S. 495

Antow, P. 504

\section{B}

Bachnewa, K. 491

Baewa, I. 495

Bakalova, E. 503, 505

Balcerak, W. 485

Balcerak, W. (oprac.) 478, 481

Balcerak, W. (red.) 477, 478, 481

Balcerak, W. (red. nauk.) 478, $481,485,494$

Barlieva, S. 505

Bartelski, L. M. 467, 471, 477

Basaj, M. 482

Batowski, H. 465

Bednarek, M. 511

Biesiada, J. 464, 478

Biołczew, B. 477

Błońska, M. 487

Bońkowski, R. 508

Borowiak, P. 506

Bożankowa, R. 504

Brosz, A. 465, 466

Buchwald-Pelcowa, P. 487

Bułhak, H. 487

Bylina, S. 471

C

Canew, C. 491

Češmedžiev, D. 503

Češmedžijev, D. 505

Chichikova, K. 498

Chomatian, D. 505

Christowa, N. 495

Cieślak, T. 477

Cwetkow, P. 485
Cybart, N. 498, 502

Cyrankiewicz, J. 470

Czachowska, J. 471, 478

Czajka, H. 469, 470, 472, 477, 479,482

Czantor, B. 465

Czekalski, T. 504

Czerwiński, Z. 471

Cziczowska, W. 478

Czubiński, A. 477

Свидзиньский, Е. 490

\section{D}

Damianowa, E. 482, 485, 495

Dankowicz, H. 466

Darasz, Z. 491

Dąbek, T. 470. Zobacz też Dąbek-Wigrowa, $\mathrm{T}$.

Dąbek-Wirgowa, T. 463, 469, $472,475,477,482$

Dąbek-Wirgowa, T. (red. nauk.) 482

Dąbek-Wirgowa, T. (wybór, przekład, wstęp) 480

Dimitrowa, E. 504

Dimitrow, C. 470

Dinekow, P. 470. Zobacz też Динеков, П.

Długosz, N. 508

Dobrijanow, T. (oprac.) 478, 481

Dojnow, D. 470

Dolata, H. 491

Drzewiecka, E. 502, 503, 506, 511

Duda, J. 511

Dymitrow, D. 470

Dynak, J. 481, 482

Dziadul, P. 511

Dziki, S. 482

Dżurow, D. 470
F

Farion, M. 502

Firlej, A. 512

Fleischerowicz, Ł. 511

G

Gabe, D. 465, 469

Gałązka, W. 478, 485, 491 Gałązka, W. (tłum. i oprac.) 480, 481

Gapska, D. 511

Garlicka, A. 485, 495

Genow, C. 477

Georgiew, E. 477. Zobacz też Георгиев, Е.

Giza, A. 488, 493

Giza, A. (oprac.) 499

Głogowski, P. 464, 491

Gołek-Sepetliewa, D. 507

Graczyk, E. 504

Grochowina, M. 477

Grzelak, U. 490

\section{H}

Hemmerling, Z. 477

Hensel, W. 480

Hoffmann, B. 508

Holzer, J. 482

\section{I}

Ikonomow, D. 471

Isusow, M. 477, 485

Ivanowa, D.. Zobacz Иванова, Д.; Zobacz też Iwanowa, D.

Ivanowa, D. (red.) 502

Iwanowa, D. 497

Iwanowa-Girginowa, M. 491

Iwanow, G. 470

Iwanow, W. 470 
Iwasiów, I. 504

\section{J}

Jackowicz, J. 476, 478, 482, 486, 489

Jakubowski, I. 470

Jankowska, M. 498

Janusz, J. 498

Jaroszewicz-Kleindienst, B. 471

Jaruzelski, W. 470

Jaworska, L. 511

Jóźwiak, W. 491, 496, 501, 508, 511,512

Jóźwiak, W. (red.) 512

Jóźwiak, W. (red. nauk.) 510

Juda, C. 491, 493

$\mathbf{K}$

Kacarkowa, W. 485

Kaczmarek, U. 486

Kałkandżijewa, D. 494

Kamieńska, A. 471

Kamiński, J. 471

Karabełowa, M. (red., wybór) 504

Karpaczewa, M. 477

Karpińska, H. 491

Karpińska, H. (tłum.) 504

Kaszlej, A. 487

Kaszlej, A. (oprac.) 492, 495

Kawecka, A. (tłum.) 499

Kijas, A. 496

Klejn, Z. 478, 481, 489, 494

Klimecki, M. 485

Kolewa, R. 504

Kołomiejczyk, N. 477

Komsałowa, R. 494

Konopnicka, M. 471

Konstantinowa, E. 491. Zobacz też Константинова, Е.

Korytkowska, M. 474

Korytkowska, M. (red.) 491

Koseski, A. 470, 474, 475, 478, $480,481,482,485$
Kosew, D. 470

Koszel, B. 479

Kot, W. 477

Kozowski, F. 470

Krupski, B. 479

Krzepkowski, S. 489

Krzeszewska, K. 498, 502

Księżarczyk, F. 470

Kuczyńska, M. 503

Kuev, K. M. 465, 466. Zobacz też Куев, К. М.

Kuew, K. M. 477

Kwater, J. 481

\section{L}

Lelewska, K. 502

Lewaszkiewicz, T. 511

Lewaszkiewicz, T. (red.) 502

Lis, I. 491

Lis-Wielgosz, I. (red. nauk.) 510

Ljubenowa, L. 495

Lorentz, S. 470

Lubańska, M. 509

Lyanguzov, P. 498

$\mathbf{L}$

Łyczko-Grodzicka, B. 480

\section{M}

Mach, W. 471

Maciejewska, A. (tłum.) 505

Maciejewski, S. 477

Madany, E. 471

Magnuszewski, J. 470, 477, 479, 481,482

Magnuszewski, J. (red. nauk.) 469

Majewski, K. 470, 477

Majuk, E. 502

Malicka, M. 502

Malinowski, A. 498

Malinowski, A. (oprac.) 499, 500, 504
Malinowski, M. 470

Małdżiewa, W. (red.) 511

Manczew, K. 494

Mateew, B. 478

Medyńska, W. 471

Michułka, D. 512

Migew, W. 482. Zobacz też Мигев, В.

Mikołajczak A. W. 491, 496

Mikołajczak A. W. (red.) 496

Miłoszewska, K. 511

Minczew, G. 491, 493, 505.

Zobacz też Минчев, Г.

Minczew, G. (oprac.) 505

Minczew, G. (przedm.) 499

Minczew, G. (red.) 491, 503

Minczew, G. (wybór i red.)

499

Minczew, G. (wybór i wstęp) 492, 499

Miodyński, L. 497, 508, 512

Miszkow, G. 470

Mleczko, J. 500, 508

Mokrzycka, A. 506

Moroz-Grzelak, L. 464, 491, 495, 507,511

Mostowska, M. 506

Moszyński, L. 481

Możejko, E. 467, 468

Mysielski, Ł. 498, 502, 503

\section{$\mathbf{N}$}

Nakow, A. (red.) 478, 481

Narbutt, O. 487

Nasiłowska, A. 504

Nasiłowska, A. (red., wybór) 504

Naumow, A. 472, 487, 491, 511

Naumow, A. (konsult. naukowa) 506

Naumow, A. (oprac.) 492, 495

Naumow, A. (red.) 486

Naumow, A. (tłum.) 505 
Naumow, E. (oprac.) 492, 495

Niedziela, Z. 479

Niemiec, J. 465

Nikołow, E. 470

Nowosad, A. 501

$\mathbf{O}$

Obodowski, J. 481

Olcha, A. 471

Orzechowska, H. 480

$\mathbf{P}$

Pańczyk, H. 479

Parnicki-Pudełko, S. 479

Paszkiewicz, J. 496

Pavlov, T. 466

Pawlik, N. 498

Petrov, I. 465, 506

Petrow, I. (red.) 503

Petrow, S. 470

Pęgierska-Piotrowska, R. 471

Pidłypczak-Majerowicz, M. 487

Piechowiak, M. B. (il.) 499

Pietrzak-Thebault, J. 511

Piwarski, K. 465

Pollak, S. 466

Popowa-Totewa, S. 494

Popowa, W. 477

Prałat, E. 511

Pytlak, M. 502

\section{$\mathbf{R}$}

Raczewa-Stratijewa, L. 474

Radewa, S. 467, 477, 483

Reczek, N. 502

Reychman, J. 471

Rękas, J. (red.) 507

Rubacha, J. 496, 509

Rubacha, J. (oprac.) 499, 500, 504

Rubach, L. 465, 468

Rusek, J. 477, 481, 482

Rusek, J. (red.) 480, 486
Russocka, J. 471

\section{S}

Sajkowski, W. 511

Semerdżijew, A. 470

Siatkowska, E. 503

Siatkowski, J. 481

Siatkowski, J. (red.) 479

Siedlecka, S. 462, 509

Sieradzki. J. 465

Sierpowski, S. 479

Simeonova-Konach, G. 511

Simeonova-Konach, G. (red) 492

Simeonowa-Konach, G. 497, 504. Zobacz też Simeonova-

-Konach, G.

Skowronek, J. 472, 473, 479, 480, 485

Skowronek, M. 501, 503, 505

Skowronek, M. (oprac.) 505

Skowronek, M. (red.) 503

Skowronek, M. (tłum.) 505, 506

Skowronek, M. (wybór i red.) 499

Slavova, M. 512

Sławski, F. 465, 467, 477, 479, 483

Sochacki, Sz. (red.) 508

Solak, E. 487, 491, 502

Sotirow, P. 506

Stachurski, E. 470

Stawecki, P. 495

Stawowy-Kawka, I. 496

Stefański, M. 464, 491

Stępniak, W. 485

Stępnik, K. 508

Stoew, S. 471

Stojanowa, W. 495

Stojanow, L. 466

Stojanow, M. 470

Stradomski, J. 511

Stradomski, J. (oprac.) 492, 495

Sujecka, J. 482, 487, 490, 491
Swoboda, W. 479

Sydor, J. 490

Szafrańska, A. 498

Szolginowa, W. 464, 468

Szperlik, E. 498

Szudrowicz, A. 498

Szulc W. (red.) 496

Szwat-Gyłybowa, G. 482, 484, 491, 497, 506, 512

Szwat-Gyłybowa, G. (red.) 463

Szwat-Gyłybowa, G. (red. nauk.) 506

Szwat-Gyłybow, G. 477. Zobacz też Szwat-Gyłybowa, G.

Szydłowski, R. 465

\section{Ś}

Śliziński, J. 470, 471

Śliziński, J. (red.) 471

Świdziński, J. (red.) 490

Świerczyński, J. 471

Świerczyński, J. (wybór i opracowanie) 470

$\mathbf{T}$

Taczyńska, K. (red.) 508, 511

Tanty, M. 473, 485, 492

Todew, I. 494

Todorov, O. 481

Todorow, P. 471

Tomaszewski, J. 476, 480, 483

Toszkowa, W. 495

Toszkow, J. 471

Trajkowa, E. 504

Trojanowski, S. 465

Twardowska, A. (red.) 511

Tymieniecka, A. 470

$\mathbf{U}$

Usakiewicz, K. 512

W

Waczewa, A. 504 
Walczak-Mikołajczakowa, M. Wierzbicki, J. 482 491, 496, 500, 503, 508, 511,512

Walczak-Mikołajczakowa, M. (red. nauk.) 490, 498

Walichnowski, T. 477

Walkiewicz, W. 483

Wasilewski, T. 470, 473, 480, 485

Weczewa, J. 485, 494

Weralski, M. 465

Widerszal, L. 465

Wierzbicka, K. 471, 480

Wierzbicki, A. 494

A

Ангелов, П. 479

Б

Бояджиев, Т. 477

B

Василенко, В. 490

$\Gamma$

Ганчева, Б. 490

Георгиев, Е. 471. Zobacz te $\dot{z}$ Georgiew, E.

Генов, Ц. 480

Д

Дамянова, Е. 480, 481

Дамянов, С. 480

Дунков, Д. 487

Дживтерева, С. 508

Динеков, П. 471, 481. Zobacz też Dinekow, $\mathrm{P}$.

Дунков, Д. 487

И

Иванова, Д. 487, 490, 491. Zobacz też Iwanowa, D.
Witkowski, W. (red.) 486

Wojtasik, J. 485

Wojtczak, M. 497, 498, 502

Woźniak, E. 503

Woźniakowski, K. 481, 482

Woźnica, R. 510

Wrocławski, K. 491, 503, 508

Wygnańska, J. 508

$\mathbf{Z}$

Zalewski, E. 465

Zawilski, A. 474

\section{Cyrylica}

Иванчев, С. 477

$\mathbf{K}$

Караденизова, И. 502

Константинова, Е. 481. Zobacz też Konstantinowa, E.

Куев, К. М. 471, 479. Zobacz też Kuev, K. M.

Л

Луканов, А. 481

M

Мечев, К. 479

Мигев, В. 480

Минчев, Г. 481

H

Николова, Я. Ив. 480

O

Огнянов, Л. 480

\section{П}

Паскалева, В. 471

Петров, П. 480

Поборникова, С. 480
Zdancewicz, T. (red.) 479

Zečević, M. (red.) 508

Zieliński, B. (red.) 496, 512

Zlatew, Z. 478

Złatkow, R. 471

Znamierowska-Rakk, E. 475, 484, 485, 494, 496, 497

$\dot{\mathbf{Z}}$

Żejmo, B. 505, 511

Żiwkow, T. 470

Żmigrodzki, M. 473, 488

Żurek, P. 494

Примов, Б. 480

Петровска-Кузманова, К. 508

P

Русинов, Р. 477

Рождественская, М. В. 503

C

Сапарев, О. 490

Селимски, Л. 477

Симеонова-Конах, Г. 512. Zobacz też Simeonowa-Konach, G.

Стојковски, Б. 508

Сувајџић, Б. 508

$\mathbf{T}$

Тодорова, Т. 502

Ц

Цанева, К. 481

Цветкова, Б. А. 477

\section{III}

Шишкова, Т. 479 